UNIVERSIDADE DE SÃO PAULO

ESCOLA DE ENFERMAGEM

HÁBITOS DE HIGIENE GENITAL E INFECÇÃO

AUTORREFERIDA NO TRATO URINÁRIO NA GRAVIDEZ

MARIANA TURIANI

São Paulo

2009 
MARIANA TURIANI

\section{HÁBITOS DE HIGIENE GENITAL E INFECÇÃO AUTORREFERIDA NO TRATO URINÁRIO NA GRAVIDEZ}

Dissertação apresentada à Escola de Enfermagem da Universidade de São Paulo, para obtenção do título de Mestre em Enfermagem.

Orientadora:

Prof. ${ }^{\text {a Dr. }}$ - Luiza Akiko Komura Hoga 


\section{AUTORIZO A REPRODUÇÃO TOTAL OU PARCIAL DESTE TRABALHO, POR QUALQUER MEIO CONVENCIONAL OU ELETRÔNICO, PARA FINS DE ESTUDO E PESQUISA, DESDE QUE CITADA A FONTE.}

Assinatura: Data:

\section{Catalogação na Publicação (CIP) \\ Biblioteca "Wanda de Aguiar Horta" \\ Escola de Enfermagem da Universidade de São Paulo}

Turiani, Mariana.

Hábitos de higiene e infecção autorreferida no trato urinário na gravidez. / Mariana Turiani. - São Paulo, 2009.

$94 \mathrm{p}$.

Dissertação (Mestrado) - Escola de Enfermagem da Universidade de São Paulo.

Orientadora: Prof. ${ }^{a}$ Dr. ${ }^{a}$ Luiza Akiko Komura Hoga.

1. Trato urinário 2. Infecções bacterianas 3. Gravidez 4. Saúde da mulher 5. Higiene 6. Puerpério. I. Título. 
Nome: Mariana Turiani

Título: Hábitos de higiene genital e infecção autorreferida no trato urinário na gravidez.

Dissertação apresentada à Escola de Enfermagem da Universidade de São Paulo para obtenção do título de Mestre em Enfermagem.

Aprovado em:

Banca Examinadora

Prof. Dr. Instituição:

Julgamento: Assinatura:

Prof. Dr. Instituição:

Julgamento: Assinatura:

Prof. Dr. Instituição:

Julgamento: Assinatura: 
Dedico a Deus, que a cada dia abençoa e dispõe de pessoas maravilhosas ao meu lado: Meu marido Marcelo, meu amor eterno, que me faz feliz diariamente, com muita paixão, respeito e cumplicidade. Minha mãe Rejane, por seu carinho, dedicação e amor incondicional. Muito obrigada, pois vocês foram imprescindíveis em mais essa etapa de minha vida. 


\section{AGRADECIMENTOS}

À Prof. a Dr. a Luiza Akiko Komura Hoga, orientadora dedicada, responsável e criteriosa, por quem tenho imenso carinho pela oportunidade de desfrutar de seus valiosos ensinamentos.

À Prof. ${ }^{a}$ Dr. a Maria do Rosário Dias de Oliveira Latorre, pela dedicação e contribuição, na assessoria estatística e nas precisas sugestões.

Às Prof. ${ }^{a}$ Dr. ${ }^{\underline{a}}$ Maria Helena Baena de Moraes Lopes e Prof. ${ }^{a}$ Dr. ${ }^{a}$ Sonia Maria Junqueira Vasconcellos de Oliveira, pelas contribuições e sugestões apresentadas por ocasião do exame de qualificação.

A meu pai Luiz Henrique e meus irmãos Paula e Daniel, pelos inúmeros momentos vividos e pelo simples fato de existirem e serem minha família querida.

A meus amigos e familiares, pela amizade verdadeira e momentos únicos compartilhados.

Ao Hospital e Maternidade São Camilo - Santana, em especial, Camila Pereira, Rosemeire Tamazato, Tatiana Gambetta e Wilma Cintra, pelo apoio fundamental e incentivo constante.

Ao Conjunto Hospitalar do Mandaqui, em especial, ao Departamento de Ginecologia e Obstetrícia, pela permissão do estudo com as pacientes.

A Luciana Magnoni Reberte, pela contribuição imprescindível e apoio.

Ao Marcello Batista Pimentel, pela colaboração cuidadosa na etapa da formatação desta pesquisa.

À professora Ivone Borelli, pela cuidadosa correção ortográfica de Língua Portuguesa, que contempla às novas regras do acordo ortográfico. 
Ao Departamento de Enfermagem Materno-Infantil e Psiquiátrica da Escola de Enfermagem da Universidade de São Paulo, pelo apoio em todas as etapas da realização deste trabalho.

Aos funcionários da secretaria da pós-graduação, pela atenção e disponibilidade durante todo o percurso desta trajetória.

Aos membros do grupo de pesquisa Núcleo de Assistência ao Autocuidado da Mulher - NAAM, pela atenção na realização desta pesquisa.

A todas as puérperas que dividiram comigo suas experiências e intimidade.

Ao Conselho Nacional de Desenvolvimento Científico e Tecnológico (CNPq), pelo auxílio concedido na forma de bolsa produtividade para a orientadora desta pesquisa.

A você que dispensou um pouco de sua atenção para com este trabalho, meus sinceros agradecimentos. 
TURIANI M. Hábitos de higiene genital e infecção autorreferida no trato urinário na gravidez. [Dissertação]. São Paulo (SP): Escola de Enfermagem da USP; 2009.

\section{RESUMO}

Introdução: a infecção do trato urinário (ITU) é uma das complicações mais frequentes na gravidez, repercute negativamente sobre os índices de morbidade e mortalidade perinatal. Objetivo: o objetivo desta pesquisa foi verificar a associação entre as práticas de higiene genital e sexual e a ocorrência de ITU na gravidez. Casuística e método: foi realizado um estudo transversal, exploratório e descritivo de base hospitalar. Os dados foram coletados com $220(\mathrm{~N})$ puérperas que receberam assistência ao parto em um hospital público localizado na Cidade de São Paulo. Um formulário estruturado foi utilizado para coletar os dados com as puérperas que foram introduzidos em um banco de dados do Epi Info e analisados no Programa estatístico Statistical Package for Social Sciences (SPSS) for Windows versão 12.0. O Teste Qui-Quadrado foi feito para verificar a existência de associação entre as variáveis independentes e a ocorrência da ITU na gravidez. Foram consideradas significativas todas as associações, cujos resultados apresentaram $p<0,05$. Resultados e considerações finais: Quanto às características sociodemográficas das puérperas, a maior proporção tinha idade entre 20 a 29 anos $(51,8 \%)$, estudou até o ensino médio $(46,4 \%)$, era católica $(48,7 \%)$, tinha filhos $(60 \%)$ e parceiro fixo $(91,8 \%)$. Seus parceiros apresentaram características semelhantes. Não foi identificada existência de associação significativa $(p<0,05)$ entre as características sociodemográficas da gestante e seu parceiro, da assistência pré-natal, paridade e tipo de parto, disponibilidade de banheiro, higienização das roupas íntimas, hábito de uso de absorventes higiênicos, práticas de higiene genital das puérperas e parceiros antes e após as eliminações vesicointestinais e no coito, hábitos sexuais e a ocorrência da ITU na gravidez. A ocorrência desta patologia na gravidez foi autorreferida por $33,2 \%$ das puérperas. Chamou atenção o fato de duas puérperas $(0,9 \%)$ não realizarem higiene genital, após as eliminações intestinais. Informações sistematizadas sobre os hábitos de higiene genital devem ser obtidas para 
que as demandas individuais sejam identificadas e atendidas. A inexistência de associações significativas entre as variáveis estudadas nesta pesquisa e a ocorrência da ITU na gravidez indicou que outras dimensões da vida de gestante devem ser enfocadas nas futuras pesquisas.

PALAVRAS-CHAVE: Gravidez. Infecção no trato urinário. Higiene. Saúde da mulher. Enfermagem. 
TURIANI M. Genital hygiene habits and self-referred urinary tract infection during pregnancy. [Dissertation]. Sao Paulo (SP): Nursing School, University of São Paulo; 2009.

\section{ABSTRACT}

Introduction: Urinary tract infection (UTI), which is one of the most frequent complications during pregnancy, negatively affects perinatal morbidity and mortality ratios. Objective: This research aimed to verify the association between genital and sexual hygiene practice and the occurrence of UTI during pregnancy. Cases and method: A cross-sectional, exploratory and descriptive hospital-based study was carried out. Data were collected from $220(\mathrm{~N})$ puerperal women who received delivery care at a public hospital in São Paulo City, Brazil. A structured form was used for data collection. Data were fed into an Epi Info database and analyzed in Statistical Package for Social Sciences (SPSS) for Windows version 12.0. The Chi-Square Test was performed to check for associations between the independent variables and the occurrence of UTI in pregnancy. All associations with $p<0.05$ were considered significant. Conclusions and final considerations: As to these women's sociodemographic characteristics, a majority was between 20 and 29 years old $(51.8 \%)$, finished secondary education (46.4\%), was catholic $(48.7 \%)$, had children $(60 \%)$ and a fixed partner $(91.8 \%)$. Their partners presented similar characteristics. No significant association $(p<0.05)$ was identified between the sociodemographic characteristics of the pregnant woman and her partner, prenatal care, parity and delivery type, availability of bathroom, washing of intimate clothing, habit to use sanitary towels, genital hygiene practices of the puerperal women and their partners before and after urinary-intestinal eliminations and after coitus, sexual habits and the occurrence of UTI during pregnancy. The occurrence of this disease during pregnancy was self-referred by $33.2 \%$ of the women. It was remarkable that two womens $(0.9 \%)$ did not perform genital hygiene after intestinal eliminations. Systemized information on genital hygiene habits should be obtained with a view to identifying and responding to individual demands. The lack of significant associations between the research variables and the 
occurrence of UTI during pregnancy indicated that other dimensions of the pregnant woman's life should be focused on in future research.

KEYWORDS: Pregnancy. Urinary Tract Infections. Hygiene. Women's Health. Nursing 


\section{LISTA DE TABELAS}

Tabela 1 - Características sociodemográficas das puérperas, São Paulo, 2008. $\mathrm{N}=220$

Tabela 2 - Características sociodemográficas dos parceiros. São Paulo, 2008. $\mathrm{N}=220$

Tabela 3 - Características dos sintomas, ocorrência da ITU na gravidez e tratamento. São Paulo, 2008. N=220.

Tabela 4 - Características do pré-natal, paridade e tipo de parto das puérperas. São Paulo, 2008. $\mathrm{N}=220$.

Tabela 5 - Existência de banheiro no domicílio e no local de trabalho das puérperas. São Paulo, 2008. N=220.

Tabela 6- Características da higienização das roupas íntimas das puérperas. São Paulo, 2008. N=220

Tabela 7 - Uso de absorventes na gravidez. São Paulo, 2008. N=220

Tabela 8 - Hábitos de higiene genital após eliminações vesicointestinais na gravidez. São Paulo, 2008. $\mathrm{N}=220$

Tabela 9 - Hábitos de higiene genital após eliminações vesicointestinais dos parceiros. São Paulo, 2008. N=220

Tabela 10 - Hábitos sexuais das puérperas durante a gravidez. São Paulo, 2008. $\mathrm{N}=220$

Tabela 11 - Hábitos de higiene das puérperas antes e após o coito na gravidez. São Paulo, 2008. $\mathrm{N}=220$

Tabela 12 - Hábitos de higiene dos parceiros antes e após o coito na gravidez. São Paulo, 2008. $N=220$

Tabela 13 - Existência de orientações sobre higiene genital na assistência pré-natal. São Paulo, 2008. N=220

Tabela 14 - Características sociodemográficas das puérperas, segundo ocorrência da ITU na gravidez. São Paulo, 2008.

Tabela 15 - Características sociodemográficas dos parceiros, segundo ocorrência da ITU na gravidez. São Paulo, 2008.

Tabela 16 - Características do pré-natal, paridade e tipo de parto anterior, segundo a ocorrência da ITU na gravidez. São Paulo, 2008.......54 
Tabela 17 - Existência de banheiro na residência e no trabalho, segundo a ocorrência da ITU na gravidez. São Paulo, 2008.

Tabela 18 - Características da higienização das roupas íntimas, segundo a ocorrência da ITU na gravidez. São Paulo, 2008.

Tabela 19 - Uso de absorvente higiênico, segundo a ocorrência da ITU na gravidez. São Paulo, 2008.

Tabela 20 - Hábitos de higiene genital após eliminações vesicointestinais, segundo a ocorrência da ITU na gravidez. São Paulo, 2008.......57

Tabela 21 - Hábitos de higiene genital após eliminações vesico-intestinais dos parceiros, segundo a ocorrência da ITU na gravidez. São Paulo, 2008.

Tabela 22 - Características dos hábitos sexuais, segundo a ocorrência da ITU na gravidez. São Paulo, 2008.

Tabela 23 - Hábitos de higiene genital das puérperas antes e após o coito, segundo a ocorrência da ITU na gravidez. São Paulo, 2008.......60

Tabela 24 - Hábitos de higiene genital dos parceiros antes e após o coito, segundo a ocorrência da ITU na gravidez. São Paulo, 2008.......60

Tabela 25 - Existência de orientação sobre higiene genital para gestantes e parceiros, segundo a ocorrência da ITU na gravidez. São Paulo,2008 


\section{SUMÁRIO}

1 INTRODUÇÃO

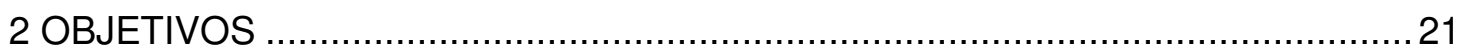

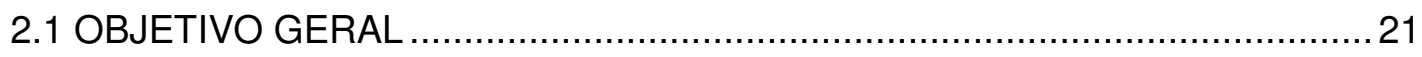

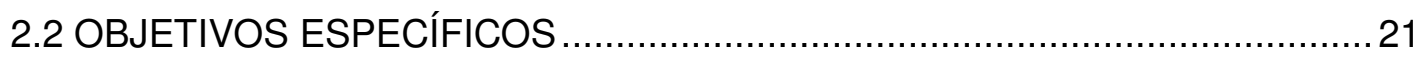

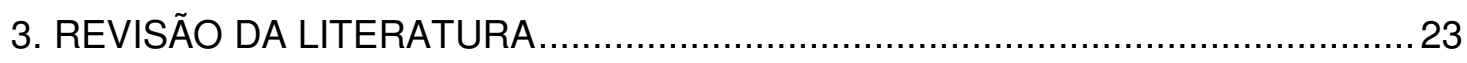

3.1 ALTERAÇÕES ANATOMOFISIOLÓGICAS DO APARELHO URINÁRIO NA GRAVIDEZ E AS NECESSIDADES DE CUIDADO COM A HIGIENE GENITAL .. 23

3.2 INFECÇÃO URINÁRIA NA GRAVIDEZ E A MORBIDADE E MORTALIDADE PERINATAL

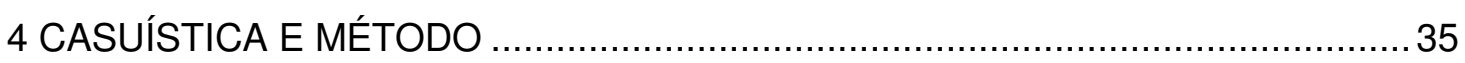

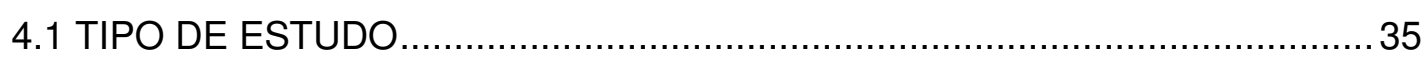

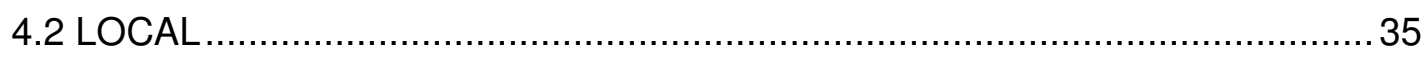

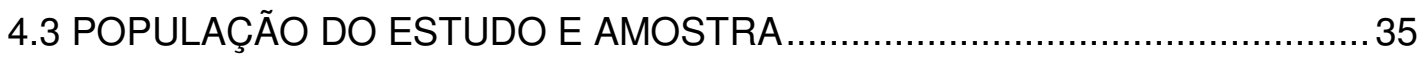

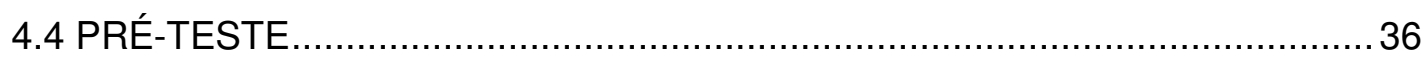

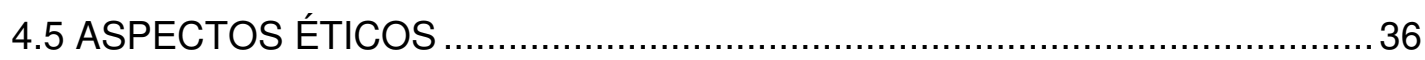

4.6 VARIÁVEIS ESTUDADAS E INSTRUMENTO DE COLETA DE DADOS.........37

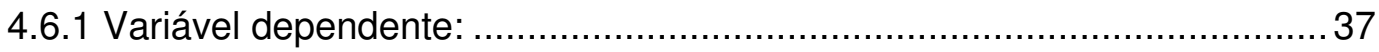

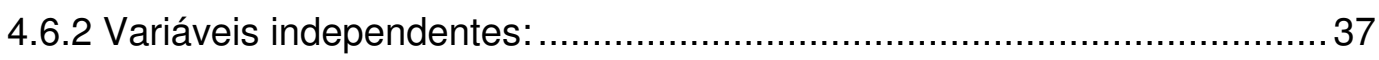

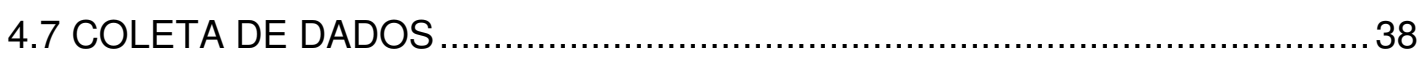

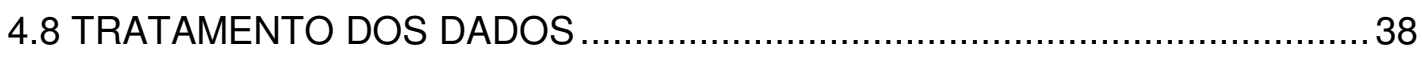

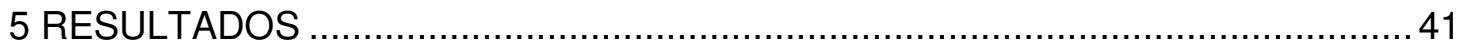

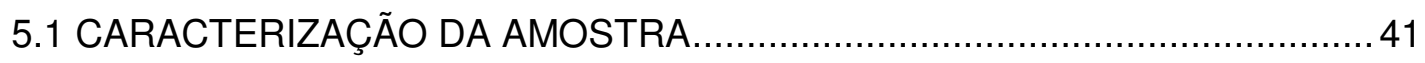

5.2 ASSOCIAÇÃO ENTRE OCORRÊNCIA DA ITU E AS CARACTERÍSTICAS SOCIODEMOGRÁFICAS DA PUÉRPERA E DO PARCEIRO ………...................5

5.3 ASSOCIAÇÃO ENTRE OCORRÊNCIA DE INFECÇÃO DO TRATO URINÁRIO E AS CARACTERÍSTICAS DO TIPO DE PARTO, PRÉ-NATAL E PARIDADE

5.4 ASSOCIAÇÃO ENTRE OCORRÊNCIA DE INFECÇÃO DO TRATO URINÁRIO E A DISPONIBILIDADE DOS BANHEIROS NA RESIDÊNCIA E TRABALHO DA PUÉRPERA 
5.5 ASSOCIAÇÃO ENTRE OCORRÊNCIA DE INFECÇÃO DO TRATO URINÁRIO E AS CARACTERÍSTICAS DA HIGIENIZAÇÃO DAS ROUPAS ÍNTIMAS

5.6 ASSOCIAÇÃO ENTRE OCORRÊNCIA DE INFECÇÃO DO TRATO URINÁRIO E CARACTERÍSTICAS DO USO DE ABSORVENTE NA GRAVIDEZ 56

5.7 ASSOCIAÇÃO ENTRE OCORRÊNCIA DE INFECÇÃO DO TRATO URINÁRIO E AS CARACTERÍSTICAS DE PRÁTICAS DE HIGIENE GENITAL ...57

5.8 ASSOCIAÇÃO ENTRE OCORRÊNCIA DE INFECÇÃO DO TRATO URINÁRIO E AS CARACTERÍSTICAS DOS HÁBITOS SEXUAIS NA GRAVIDEZ58

5.9 ASSOCIAÇÃO ENTRE OCORRÊNCIA DE INFECÇÃO DO TRATO URINÁRIO E AS CARACTERÍSTICAS DOS HÁBITOS DE HIGIENE ANTES E APÓS O COITO

5.10 ASSOCIAÇÃO ENTRE OCORRÊNCIA DE INFECÇÃO DO TRATO URINÁRIO E EXISTÊNCIA DE ORIENTAÇÕES SOBRE HIGIENE GENITAL PARA A PUÉRPERA E SEU PARCEIRO NA GRAVIDEZ

6 DISCUSSÃO 63

7 CONCLUSÕES. 74

8 CONSIDERAÇÕES FINAIS 77

9 LIMITAÇÕES DA PESQUISA E RECOMENDAÇÕES PARA NOVOS ESTUDOS 80 REFERÊNCIAS 82

APÊNDICES 88 
INTRODUÇÃO (20) 


\section{INTRODUÇÃO'}

A infecção do trato urinário (ITU), seja ela sintomática ou assintomática, é uma das complicações mais frequentes na gravidez (MacLean, 2001). Esta patologia representa a segunda maior causa de morbidade obstétrica e um dos principais fatores associados ao aborto, ao parto prematuro e à infecção ovular (Brasil, 2000).

As complicações derivadas da ITU, em razão de sua relevância para os resultados obstétricos e neonatais, devem ser evitadas, pois causam muitos prejuízos à saúde da gestante e do recém-nascido. Por sua vez, esta problemática produz efeito direto sobre índice de morbidade e mortalidade perinatal (Brasil, 2000).

A assistência pré-natal constitui momento relevante para prestar atendimento ampliado às mulheres. Em países como o Brasil, em razão da precariedade da assistência médica, o rastreamento sistematizado das condições de saúde das gestantes e o adequado atendimento de suas necessidades de saúde são aspectos muito importantes e devem ser relevados. Estima-se que, para muitas mulheres, a assistência pré-natal seja a única oportunidade para receber atendimento no âmbito da saúde (Belfort, 1998).

A enfermeira obstetra possui os conhecimentos e habilidades necessários para prestar assistência às gestantes, podendo contribuir de maneira significativa para reduzir os índices de mortalidade materna e perinatal. Esta profissional pode desempenhar seu papel na assistência prénatal visando a prevenir a ocorrência de complicações durante o ciclo gravídico e puerperal. A atuação pode ser realizada, mediante o desenvolvimento de grupo de gestantes, consultas de enfermagem, elaboração de vídeos e cartilhas educativas, entre outros recursos, cujo conjunto objetiva promover a saúde da mulher nesta fase importante de sua vida (Brasil, 2001; Reberte, 2008).

\footnotetext{
1 A revisão de língua portuguesa desta dissertação contempla as novas regras do acordo ortográfico
} 
A análise sobre a assistência pré-natal prestada pela enfermeira obstetra permitiu concluir que a participação mais efetiva desta profissional na atenção integral à mulher contribuiu para melhorar a assistência às gestantes. Medidas como a descentralização das atividades de assistência à mulher e a incumbência do cuidado dos casos de menor complexidade direcionada àquela profissional permitiram que o médico dedicasse maior tempo às gestantes que apresentavam alto risco obstétrico (Barros, 1990).

A expectativa da Organização Mundial da Saúde e da Organização Panamericana de Saúde é de que as enfermeiras obstetras assumam, cada vez mais, o compromisso de atuar efetivamente na assistência à mulher no ciclo gravídico e puerperal, com vistas a prevenir a ocorrência de doenças e promover a saúde das mulheres (Brasil, 1995). Neste contexto, emerge a relevância da atuação da enfermeira, sobretudo, seu papel na esfera da educação para o autocuidado da gestante.

No campo da assistência à saúde, a focalização de problemas e a identificação dos fatores que os causam constituem etapas fundamentais para a proposição de ações de intervenção específica. Desse modo, avaliouse a importância da identificação de problemas relacionados à higiene genital entre as gestantes e sua possível associação com a ocorrência da infecção do trato urinário.

A literatura científica demonstrou que a prevalência dessa patologia na gravidez variou entre 5\% e 10\% (Andriole, 1992; Delcroix et al, 1994; Palacios et al, 2001), 15\% (Krcmery, Hromec, Demeova, 2001) e 25\% (Quiroga-Feuchter et al, 2007). Os pesquisadores enfocam as relações entre as inúmeras variáveis relacionadas à ITU e os resultados obstétricos e neonatais em seus estudos. Quanto às causas desta patologia, são enfocadas, sobretudo, as alterações no trato urinário próprias da gestação e suas relações com a ocorrência da ITU. Entretanto, no que se refere à relação entre os hábitos de higiene genital e sexual, vestuário e condições socioeconômicas das gestantes e a ocorrência da ITU na gravidez, foi identificada apenas uma pesquisa em toda a literatura, em âmbito mundial (Sheikh et al, 2000). 
Esse estudo foi desenvolvido no Paquistão e os pesquisadores concluíram que não existia associação entre as condições socioeconômicas, a higiene pessoal, nível educacional, higiene genital pós-coital, características de uso de roupas íntimas e ocorrência da ITU na gravidez. Nessa pesquisa, a única associação identificada foi entre a existência de histórico da patologia em momento anterior e sua ocorrência na gravidez atual.

$\mathrm{Na}$ literatura brasileira ou latino-americana não se encontrou estudo enfocando esse aspecto. Assim, acredita-se na relevância de estudos dessa natureza em outros contextos, tendo em vista as diferenças climáticas, sanitárias, de hábitos sexuais e de higiene, entre outros.

Além disso, estima-se que os cuidados relacionados à saúde e cujas respectivas orientações devem ser feitos com base em dados comprovados cientificamente, pois, cada vez mais tem se defendido que tais práticas devem estar pautadas nas melhores evidências. Devem ser consideradas as questões contextuais que envolvem as dimensões culturais e socioeconômicas dos usuários dos serviços de saúde, assim como as preferências individuais (Pearson et al, 2005).

Com base nessas prerrogativas, foi proposta a presente pesquisa que teve o pressuposto geral de verificar as possíveis associações entre os aspectos relacionados às instalações sanitárias utilizadas e os costumes relativos à lavagem das roupas intimas, o uso de absorventes, a higiene após as eliminações vesicais e intestinais, as práticas sexuais, as orientações recebidas quanto a estes assuntos e a ocorrência da infecção no trato urinário na gravidez. 


\section{OBJETIVOS}




\section{OBJETIVOS}

\subsection{OBJETIVO GERAL}

Verificar a associação entre as práticas de higiene genital e sexual e a ocorrência de infecção autorreferida no trato urinário na gravidez.

\subsection{OBJETIVOS ESPECÍFICOS}

Verificar a associação entre a ocorrência de infecção autorreferida do trato urinário durante a gravidez e:

- as características socioeconômicas da puérpera e parceiro;

- o tipo de parto atual, pré-natal e paridade;

- a disponibilidade de banheiro na residência e no trabalho;

- as características da higienização das roupas íntimas das puérperas;

- o hábito do uso de absorventes higiênicos externos e internos na gravidez;

- as características de higiene genital das puérperas e parceiros antes e após as eliminações vesicointestinais;

- as características dos hábitos sexuais das puérperas e parceiros na gravidez;

- as características dos hábitos de higiene adotadas pelas puérperas e parceiros antes e após o coito;

- a existência e características de orientações sobre higiene genital no pré-natal. 
REVISÃO DA LITERATURA 


\section{REVISÃO DA LITERATURA}

\subsection{ALTERAÇÕES ANATOMOFISIOLÓGICAS DO APARELHO URINÁRIO NA GRAVIDEZ E AS NECESSIDADES DE CUIDADO COM A HIGIENE GENITAL}

Uma atenção especial deve ser destinada à higiene genital na gestação. Nesta fase, ocorrem diversas modificações no aparelho urinário decorrentes do aumento da volemia materna, associada à diminuição da resistência vascular. Há o aumento da vascularização e do espaço intersticial, e o rim sofre aumento de cerca de $1 \mathrm{~cm}$ na gravidez (Neme, 2000).

Associa-se, também, o fato da uretra feminina ser relativamente mais curta que a masculina e estar localizada muito próxima da vagina. Esta característica anatômica pode favorecer a colonização do sistema urinário com micro-organismos do trato gastrintestinal (Millar, Cox, 1997).

Durante a gravidez, os níveis elevados de progesterona e prostaglandinas resultam em alterações anatômicas e funcionais do aparelho urinário. Estas modificações, tais como, aumento da complacência vesical, diminuição do tônus da musculatura e da peristalse dos ureteres, levam ao aumento da frequência urinária, da glicosúria, da formação de hidroureter e de hidronefrose fisiológica, além de alteração do pH urinário, que predispõem à ocorrência de infecção (Batista, 2002).

A sensação de irritabilidade vesical, ocasionada pelo aumento da frequência urinária, pode ser um dos primeiros sintomas de gravidez. Esta ocorrência deve-se ao fato do útero em crescimento pressionar a base da bexiga. Além disso, o efeito dos hormônios sobre o corpo da gestante produz aumento na sensibilidade do trígono vesical. Este conjunto resulta na sensação de distensão vesical, habitualmente, causada pela presença de grande quantidade de urina (Barros, Marin, Abrão, 2002). As modificações do $\mathrm{pH}$ e da dinâmica urinária favorecem a proliferação bacteriana que propicia o desenvolvimento de infecção urinária. Esta pode ser representada 
pela bacteriúria assintomática, cistite aguda ou, até mesmo, um quadro de pielonefrite aguda (Batista, 2002).

A ação relaxante da prostaciclina sobre a musculatura lisa ocasiona diminuição da tonicidade e motilidade dos órgãos do aparelho urinário. Esta condição facilita a estase urinária que favorece a ocorrência das infecções no trato urinário na gravidez (Neme, 2000). A contaminação do vestíbulo vaginal e da uretra por bactérias entéricas e sua colonização constituem fatores determinantes das infecções no trato urinário e das vulvovaginites (Halbe, 1993).

Considerando a maior suscetibilidade das gestantes à infecção urinária, as orientações a respeito dos cuidados higiênicos diários, no banho, após urinar e evacuar e nas práticas sexuais devem ser alvo da atenção dos profissionais de saúde, no decorrer da assistência pré-natal. Avaliou-se que a abordagem destes assuntos com as gestantes é fundamental para a adoção de práticas adequadas de higiene genital nos períodos grávido e puerperal (Halbe, 1993; Sunders, 2002).

A realização de higiene genital cuidadosa é recomendada durante o banho que deve ser, no mínimo, diário. Os grandes lábios devem ser separados para permitir que a espuma do sabonete, de preferência neutro, penetre no sulco interlabial, no introito vaginal, períneo e ânus. O processo de desensaboar deve ser feito com uso de água em quantidade suficiente para remover todos os resquícios do produto químico na pele. $O$ uso de desodorantes íntimos, sabonetes, perfumes e talcos, pelo fato de provocarem irritações na pele e alergia deve ser evitado (Moreira, 1986; Almeida, 2000).

Após as eliminações vesicointestinais, a vulva e o ânus devem ser lavados com água corrente. $\mathrm{Na}$ impossibilidade desta prática, a higiene precisa ser realizada pelo uso de papel higiênico. Após a micção, a região da uretra deve ser secada mediante leve compressão com papel higiênico, de preferência macio e absorvente. O mesmo procedimento deve ser realizado na região do introito vaginal (Almeida, 2000). A higienização das mãos antes e após a micção, também, é recomendada (Sunders, 2002). 
As práticas de higiene genital e suas relações com a ocorrência de infecção urinária foram estudadas em uma amostra da população de mulheres inglesas, que estavam com idade gestacional entre 9 e 13 semanas. Ficou demonstrado que $48 \%$ tinham o hábito de fazer higiene da genitália, após as micções no sentido ântero-posterior, 44\% faziam no sentido contrário, ou seja, no póstero-anterior e $8 \%$ faziam sem realizar nenhum movimento. A incidência de infecção urinária entre estas mulheres foi, respectivamente, de $18,5 \%, 25,8 \%$ e $16,1 \%$. Constatou-se um significativo aumento da incidência de infecção urinária entre as gestantes que faziam a higiene pós-micção no sentido póstero-anterior, o que permitiu concluir que o hábito de limpar os órgãos genitais externos no sentido póstero-anterior tinha associação com a ocorrência de infecção urinária na gravidez (Persad et al, 2006).

Após as evacuações, a higiene deve ser feita levando a mão por trás do corpo e limpando a região anal, em um movimento unidirecional, partindo do períneo e indo ao sentido do ânus e cóccix. Movimento contrário não deve ser realizado, porque pode determinar a contaminação da vagina e uretra pela flora entérica. A contaminação do vestíbulo vaginal e da uretra por bactérias entéricas e sua colonização constituem fatores determinantes das infecções no trato urinário e das vulvovaginites (Halbe, 1993; Almeida, 2000; Sunders, 2002).

O Colégio Americano de Enfermeiras Obstétricas recomendou a realização desse tipo de higiene com a finalidade de manter as bactérias distantes da uretra e prevenir a ocorrência da ITU (American College NurseMidwives, 2005).

O papel higiênico deve ser usado em quantidade suficiente para garantir a realização da higiene adequada, o que pode demandar o emprego de vários pedaços. Cuidados devem ser tomados para que o papel não se despedace, caso isto ocorra, os fragmentos de papel podem permanecer na fúrcula e nos sulcos interlabiais e servirem como meio de cultura para os micro-organismos. A presença desse material na região vulvar pode servir como agente irritativo ou veículo de contaminação (Almeida, 2000). 
A higiene pós-coital deve ser restrita à vulvar e corporal, mediante uso de água e sabonete. Duchas vaginais devem ser evitadas porque esta prática modifica o equilíbrio da flora vaginal. A solução mediadora para o convívio saudável entre os órgãos genitais e o favorecimento de seu funcionamento fisiológico está na higienização adequada, antes e após a relação sexual. Portanto, esta prática deve ser adotada pelas pessoas envolvidas nas relações sexuais (Moreira, 1986).

Quanto às roupas íntimas, as mulheres devem dar preferência às calcinhas com fundo revestido de tecido confeccionado com algodão. Este tipo de material absorve as secreções fisiológicas do trato genital com maior facilidade e promove a ventilação adequada da região genital. A manutenção da vulva limpa, seca e bem arejada, o uso restrito de roupas sintéticas apertadas ao corpo e absorventes impermeáveis, a não utilização de detergentes na lavagem de roupas íntimas, visto que eles podem agir como irritantes tópicos, representam medidas apropriadas para evitar danos aos órgãos genitais da mulher (Almeida, 2000). O uso de vestimentas confortáveis e calcinhas com tecido de algodão, foi recomendado evitar o emprego prolongado de calças justas que provocam aumento do calor e umidade na área genital favorecendo o crescimento de bactérias (Sunders, 2002).

$\mathrm{Na}$ vida adulta, a incidência de infecção do trato urinário eleva-se e o predomínio no sexo feminino mantém-se, com picos de maior acometimento no início da atividade sexual, durante a gestação ou na menopausa. Estimase que cerca de $48 \%$ das mulheres apresentam pelo menos um episódio de infecção no trato urinário ao longo da vida. Na mulher, a susceptibilidade à infecção urinária deve-se à uretra mais curta e à maior proximidade do ânus com o vestíbulo vaginal e uretral. No homem, o maior comprimento uretral, maior fluxo urinário e fator antibacteriano prostático constituem fatores de proteção (Halbe, 1993; Duarte et al, 2002).

A infecção urinária significa crescimento de micro-organismos prejudiciais ao trato urinário. A bacteriúria assintomática consiste na presença de 100.000 colônias por mililitro de um único micro-organismo em 
urina coletada no jato médio e na ausência de sintomas. A bacteriúria sintomática ou cistite caracteriza-se por apresentar um quadro de infecção do trato urinário baixo com sintomas, como: disúria, polaciúria, nictúria, dor suprapúbica ao urinar e urgência urinária quando houver comprometimento do trígono vesical. Por fim, a pielonefrite caracteriza-se pelo comprometimento do trato urinário alto (ureter, pelve e parênquima renal) e incide em cerca de $2 \%$ das gestações. O quadro clínico compõe-se de febre, calafrios, dor nos flancos, náuseas e vômitos, urina turva, taquicardia, além de sintomas urinários (Delzell, Lefreve, 2000; Batista, 2002; Duarte, 2006).

Existe certo consenso quanto ao fato dos micro-organismos uropatogênicos, como a Escherichia Coli colonizarem o cólon, a região perianal e, nas mulheres, o introito vaginal e a região perineal. Posteriormente, processa-se a ascensão facultativa para a bexiga e/ou rins, pois, em condições normais, há competição entre estes micro-organismos com a flora vaginal e perineal (Halbe, 1993; Gorgas, 2008).

O espectro clínico de infecção do trato urinário é muito amplo e reúne diferentes condições (Heilberg, Schor, 2003):

- A cistite ou a aderência de bactérias à bexiga leva ao quadro de cistite bacteriana ou à infecção do trato urinário baixo;

- A pielonefrite aguda, também, denominada como infecção do trato urinário alto, reflete alterações anatômicas e/ou estruturais renais, decorre de um processo inflamatório agudo e acomete os rins e as estruturas adjacentes a esse órgão;

- A bacteriúria assintomática representa a presença de bactérias no trato urinário sem sinais ou sintomas. Para considerá-la significante e diferenciá-la de contaminação, são necessárias, pelo menos, duas uroculturas positivas para o germe;

- A síndrome uretral, diferente da condição anterior, apresenta sintomas como a disúria e maior frequência urinária. Entretanto, não é acompanhada por urocultura positiva e sim por sedimento urinário normal. 
A infecção do trato urinário, que representa uma das doenças infecciosas mais comuns durante a gravidez, apresentou frequência variável entre $5 \%$ e $25 \%$, conforme referido anteriormente. Durante a gestação, o arsenal terapêutico antimicrobiano e as possibilidades profiláticas ficam mais restritas, pois os efeitos tóxicos das drogas sobre o embrião e o feto devem ser considerados (Palacios et al, 2001; Duarte et al, 2002).

Os principais responsáveis pela ocorrência de infecção no trato urinário (ITU) são os germes gram-negativos entéricos, especialmente, a Escherichia Coli, seguidos dos demais gram-negativos como Klebsiela, Enterobacter, Pseudomonas (Marinelli et al, 2002).

O agente etiológico predominante na ocorrência de ITU é a bactéria denominada "Escherichia Coli", visto que ela é a causa de $80 \%$ a $90 \%$ das infecções. Outras bactérias gram-negativas como a Proteus mirabilis e Klebsiella pneumoniae, também são comuns, micro-organismos grampositivos, como Streptococcus do grupo B e Staphylococcus saprophyticus são menos comuns como causas de infecção urinária, assim como a Gardnerella vaginalis e Ureaplasma ureolyticum (Delzell, Lefreve, 2000).

A ocorrência de ITU com anticorpos urinários elevados para antígenos de Escherichia coli esteve associada com o aumento da incidência de trabalho de parto e parto pré-termo. O mesmo fato foi notado quando os anticorpos para antígenos do Streptococcus do grupo $B$ mostravam-se elevados na urina das gestantes (McKenzie et al, 1994).

Nos casos em que a infecção é proveniente da bacteriúria assintomática, a prevalência desta patologia na gravidez tem sido de até $10 \%$, podendo variar entre $25 \%$ e $75 \%$ do início da gestação e no terceiro trimestre. No entanto, quando as bacteriúrias não são tratadas adequadamente, podem evoluir para uma infecção sintomática, inclusive a pielonefrite (Heilberg, Schor, 2003). Na América, Europa e Austrália, as taxas de bacteriúria assintomática entre as gestantes apresentaram variação entre 12\% e 13\% (Krcmery, Hromec, Demeova, 2001). Cerca de 20\% a 40\% das gestantes com bacteriúria assintomática podem desenvolver pielonefrite na gravidez. Por sua vez, a bacteriúria assintomática representa um papel 
importante no trabalho de parto prematuro e com o baixo peso do recémnascido (Persad et al, 2006).

Entre as gestantes acometidas pela bacteriúria assintomática, os agentes mais comumente associados foram a Escherichia coli, o Staphylococcus coagulase-negativo e Citrobacter freundtt (Delzell, Lefreve, 2000). Constatou-se a ocorrência de aumento das taxas de bacteriúria e sua associação com o progredir da gestação, idade materna avançada, baixo nível socioeconômico, multiparidade, diabetes mellitus, bexiga neurogênica, antecedente de ITU, abortamento e infecção puerperal (Urbanetz, Varela, 1994).

Nos casos em que está associado à infecção por Clamídia e o histórico prévio de ITU, o risco de infecção urinária sintomática, antes da $20^{\mathrm{a}}$ semana de gestação foi duplicado e os fatores mais importantes no desenvolvimento da pielonefrite foram antecedentes da ITU, a baixa escolaridade, a infecção por Clamídia e o uso de drogas ilícitas (Pastore et al, 1999).

O principal fator de risco para o desenvolvimento da ITU sintomática é a bacteriúria assintomática. Deste modo, os testes de urocultura devem ser realizados no primeiro exame pré-natal, de preferência no primeiro trimestre da gravidez. Se o resultado for negativo, outra urocultura deve ser feita na $16^{a}$ semana de gestação. É imprescindível que a coleta da urina para exame seja realizada mediante antissepsia criteriosa, evitando a cateterização uretral em razão do risco de contaminação ascendente da bexiga (Marinelli et al, 2002).

A indicação do tratamento da bacteriúria assintomática deve ser preconizada na gravidez que deve durar, no mínimo, 7 dias e ser realizada por meio da antibioticoterapia. Frente à multiplicidade de novos antibióticos, o tratamento deve ser criteriosamente elaborado. Os esquemas terapêuticos tradicionais continuam válidos e os antibióticos mais novos presentes no mercado devem ser reservados para 0 tratamento dos casos de complicações infecciosas mais sérias (Paula, Krahe, Carvalho, 2005).

O objetivo desse tratamento foi impedir que as gestantes com bacteriúria assintomática desenvolvessem pielonefrite. $O$ tratamento antimicrobiano é norteado pelos princípios da dose e duração do tratamento, 
que devem ser proporcionais à invasão tecidual e/ou à dificuldade de erradicação das bactérias (Macejko, Schaeffer, 2007).

Antibióticos como a penicilina, a cefalosporina e a nitrofurantoina têm sido usados no tratamento de infecção urinária, sem efeito adverso para o feto. Algumas drogas devem ser evitadas durante a gravidez por causa dos efeitos adversos no feto, dentre elas, o fluoroquinolones, o cloranfenicol, a eritromicina e a tetraciclina (Macejko, Schaeffer, 2007).

A penicilina tem sido usada por muitos anos é bem tolerada, sem efeito teratogênico e historicamente essa droga tem sido utilizada como tratamento de escolha. Entretanto, estudos recentes mostraram 0 aumento da resistência das $E$. coli em relação à ampicilina e à amoxicilina. A resistência a ampicilina é de $20 \%$ a 30\% pela E. coli (Macejko, Schaeffer, 2007).

A cefalosporina também é comumente utilizada na gravidez, seus agentes são úteis para o tratamento da pielonefrite, especialmente, se houver resistência a um primeiro tratamento. Entretanto, a cefalosporina não é ativa contra Enterococcus (Lee et al, 2008).

A nitrofurantoina é uma boa escolha, pois atinge alta concentração urinária. Mas, não deve ser utilizada nos casos de pielonefrite, pois não apresenta penetração tissular. Constitui ótima escolha para pacientes alérgicas à penicilina (Macejko, Schaeffer, 2007).

A clindamicina é recomendada para gestantes com infecção de Steptococcus $B$ e alérgicas à penicilina. As sulfonamidas podem ser usadas durante os primeiro e segundo trimestres, porém não são recomendadas como primeira opção de tratamento, em razão da incidência de resistência da E. coli e toxicidade (Ferreira et al, 2005; Lee et al, 2008).

Os pesquisadores avaliaram que, embora o tratamento mediante o uso de antibióticos propicie a sua cura, não há dados suficientes para recomendar a adoção de um esquema específico para tratar a ITU sintomática na gravidez, tendo em vista que todos os antibióticos mostraramse efetivos (Vazquez, Villar, 2008).

No que diz respeito à prevenção da ITU recorrente em pacientes com bacteriúria assintomática, esta pode ser realizada, mediante a adoção de várias medidas. As principais delas são o aumento da ingestão de líquidos, a 
frequência urinária em intervalos de 2 a 3 horas, o hábito de urinar sempre antes de deitar ou após o coito, evitar o uso de diafragmas ou preservativos associados aos espermicidas, evitar banhos de espuma ou o uso de aditivos químicos na água do banho, quando este for de imersão (Heilberg, Schor, 2003).

A atuação da enfermeira na prevenção da ITU na gravidez tem sido motivada. Nesse sentido, foi recomendado o fornecimento de orientações voltadas às práticas de micção saudáveis como evitar adiar a micção e adquirir o hábito da micção antes do sono, pois estas práticas podem reduzir o tempo de multiplicação das bactérias. A prática da micção antes e depois das relações sexuais, também foi recomendada, visto que as bactérias podem penetrar no intróito uretral durante esta atividade (Sunders, 2002).

A revisão da literatura científica indicou a existência de lacunas em relação às evidências sobre as práticas de higiene genital e sua relação com a ocorrência da ITU na gravidez. Os pesquisadores destinam maior ênfase à etiologia da doença e sua associação com a anatomia e fisiologia da gravidez. Pouca abordagem é feita em relação às possíveis associações com os hábitos de vida das gestantes e seus parceiros. Esta constatação constituiu-se em uma das justificativas da proposição deste estudo.

\subsection{INFECÇÃO URINÁRIA NA GRAVIDEZ E A MORBIDADE E MORTALIDADE PERINATAL}

As gestantes são mais suscetíveis às complicações e sequelas graves decorrentes das infecções urinárias e, consequentemente, esta patologia exerce impacto sobre a morbidade e mortalidade perinatal. Complicações da gravidez têm sido associadas às infecções no trato urinário, inclusive, a hipertensão e a pré-eclâmpsia, anemia, corioamnionite, endometrite e septicemias. Gestações complicadas por ITU estão associadas ao dobro da mortalidade fetal observada em gestações normais, destacando-se o trabalho de parto e parto pré-termo, ruptura prematura de membranas amnióticas, restrição de crescimento fetal, recém-nascidos de baixo peso e óbito perinatal (Conde-Agudelo, Villar, Lindheimer, 2008). 
Dentre as complicações maternas em gestantes com ITU, está o aumento da incidência de trabalho de parto e parto pré-termo. O início do trabalho de parto pode ser desencadeado por uma resposta inflamatória com produção de quimiocitocinas e fosfolipase, mediadores da produção de prostaglandinas. Outra justificativa para o inicio do trabalho de parto é a colonização do liquido amniótico por bactérias originárias do foco infeccioso no trato urinário (Duarte et al, 2008).

Cerca de $27 \%$ dos partos prematuros podem estar relacionados a algum tipo de ITU (Ferreira et al, 2005). No caso da pielonefrite, foi verificada a existência desta associação. Aproximadamente, 15\% dos recém-nascidos deste estudo apresentavam peso ao nascimento inferior a 2.500 gramas (Gilstrap 3rd, Ramin, 2001).

A existência de relação significante entre a ocorrência da ITU na gravidez e prejuízo nos resultados perinatais, dentre ele, o baixo peso ao nascer, prematuridade, assim como a prematuridade associada ao baixo peso para a idade gestacional foi verificada em um estudo de coorte desenvolvido com 25.746 puérperas residentes nos Estados Unidos da América (Schieve et al, 1994).

Culturas endocervicais positivas mostraram associação com morbidades infecciosas materno-fetais, como ITU e infecção neonatal, sobretudo nos casos de prematuridade. Um estudo sobre a colonização bacteriana do canal cervical em gestantes com trabalho de parto prematuro ou ruptura prematura de membranas revelou que a única intercorrência materna associada à colonização endocervical foi a ocorrência da ITU. A colonização endocervical não acarretou apenas danos maternos, mas provocou, também, algumas repercussões neonatais, visto que houve associações significativas entre infecção precoce e óbito. Este dado sustentou a hipótese de que os micro-organismos patogênicos podem atingir o feto por via ascendente, com início no trato genital inferior (Lajos et al, 2008).

Em um estudo que investigou 52 casos de sepse neonatal precoce, que se refere à infecção sistêmica até 72 horas de vida, revelou que a ITU era a infecção materna com mais frequência associada à sepse, com $62,1 \%$ 
dos casos. Esta infecção também se revelou um fator importante na elevação do risco de sepse neonatal (Goulart et al, 2006).

Estudo sobre óbitos perinatais ocorridos em Pernambuco demonstrou que os fatores de risco que estiveram mais fortemente associados à mortalidade perinatal foram a prematuridade e o baixo peso ao nascer. Estes fatores eram passíveis em certo grau de influência por outros, como os assistenciais e os sócioeconômicos (Aquino et al, 2007).

O baixo peso ao nascer e a prematuridade são os fatores mais importantes na determinação da mortalidade neonatal (Kisztajn et al, 2003).

O diagnóstico precoce da ITU na gravidez e o correspondente tratamento correto são de grande valia, pois podem evitar a bacteriúria sintomática e o trabalho de parto prematuro. Impedir que estes problemas ocorram significa diminuir as taxas de mortalidade perinatal por prematuridade e baixo peso ao nascer (Palacios et al, 2001).

Portanto, a assistência pré-natal iniciada precocemente possibilita o diagnóstico e o tratamento de inúmeras complicações durante a gestação e a redução ou eliminação de fatores ou comportamentos de risco passíveis de serem corrigidos (Kisztajn et al, 2003).

Face aos dados da literatura expostos, sobre a influência da ITU, como fator de risco para a ocorrência da morbidade e mortalidade perinatal, avaliou-se a relevância de identificar a influência dos fatores comportamentais, como os hábitos de higiene no desenvolvimento desta infecção. 


\section{CASUÍSTICA E MÉTODO}




\section{CASUÍSTICA E MÉTODO}

\subsection{TIPO DE ESTUDO}

Trata-se de um estudo transversal, de base hospitalar sobre a influência das práticas de higiene genital e a ocorrência ou não da ITU durante a gravidez.

\subsection{LOCAL}

A pesquisa foi realizada no Conjunto Hospitalar do Mandaqui, localizado na zona norte da Região Metropolitana da Cidade de São Paulo. Trata-se de Instituição que presta assistência em complexidade de nível terciária a usuários do Sistema Único de Saúde (SUS).

A instituição presta atendimento a várias especialidades médicas, inclusive, ginecologia e obstetrícia. No âmbito obstétrico, presta assistência ao parto e puerpério. São atendidas todas as gestantes que procuram espontaneamente a Instituição ou são encaminhadas pelas unidades básicas de saúde de sua área de abrangência, em conformidade com os critérios estabelecidos pelo SUS. Desse modo, esta Instituição assiste também as gestantes que não fizeram pré-natal e aquelas que o realizaram com médicos que atendem gestantes que possuem convênio privado de saúde.

A assistência ao parto, cuja média mensal é de 200 partos, é inicialmente prestada no centro obstétrico e o puerpério, na unidade de alojamento conjunto, que possui 36 leitos. Estes estão dispostos em enfermarias com quatro leitos e as puérperas permanecem internadas durante no mínimo de dois dias após o parto.

\subsection{POPULAÇÃO DO ESTUDO}

A população deste estudo compôs-se de mulheres que receberam assistência ao parto e puerpério na Instituição citada. Os critérios de inclusão no estudo foram ter recebido assistência ao parto e puerpério na 
Instituição e consentir participar do estudo. O critério de exclusão foi à impossibilidade física e mental de responder às perguntas constantes no formulário.

A determinação da amostra da população obedeceu a critérios estatísticos, tendo sido tomada como base de cálculo a prevalência da ITU na gravidez que, segundo a literatura internacional, varia entre 5\% e $25 \%$.

\subsection{PRÉ-TESTE}

Com a finalidade de testar o instrumento de coleta de dados e a estratégia metodológica, ele foi aplicado em dez puérperas. Os dados obtidos no estudo piloto não foram incluídos nos resultados apresentados nesta pesquisa, apenas geraram aperfeiçoamento no instrumento.

\subsection{ASPECTOS ÉTICOS}

Os aspectos éticos da pesquisa seguiram de acordo com 0 preconizado pela Resolução $n^{\circ} 196$ de 1996 do Conselho Regional de Saúde, que trata das Diretrizes e Normas Regulamentadoras de Pesquisas em Seres Humanos (Brasil, 1996).

A coleta de dados foi realizada após aprovação do estudo pelas instâncias competentes. Primeiramente, foi obtida a aprovação do projeto de pesquisa por um Comitê de Ética credenciado no Conselho Nacional de Ética em Pesquisa (CONEP) (Apêndice 1). A seguir, foi obtida a autorização para realização da pesquisa com o responsável pelo Departamento de Ginecologia e Obstetrícia da instituição que constituiu o campo desta pesquisa.

O Termo de Consentimento Livre e Esclarecido - TCLE (Apêndice 2), em que estavam descritos os itens relativos aos aspectos éticos da pesquisa, devidamente respeitados, foi apresentado, explicado seu teor e assinado por todas as colaboradoras que se dispuseram a contribuir no estudo. O TCLE dava garantias quanto ao fornecimento de informações a respeito dos cuidados com a manutenção do anonimato das colaboradoras e a utilização dos dados apenas para finalidades científicas. 


\subsection{VARIÁVEIS ESTUDADAS E INSTRUMENTO DE COLETA DE DADOS}

\subsubsection{Variável dependente:}

- Ocorrência da ITU autorreferida durante a gravidez.

\subsubsection{Variáveis independentes:}

- Características sociodemográficas da mulher: naturalidade, idade, escolaridade, religião e trabalho;

- Características sociodemográficas do parceiro: idade, escolaridade, religião e participação nas consultas no pré-natal;

- Características de tipo(s) de parto(s), realização de pré-natal, local das consultas, participação de grupo de orientação para gestantes, paridade;

- Existência de banheiro na residência e no trabalho e exclusivo do casal;

- Características da higienização das roupas íntimas das mulheres: produtos utilizados, forma de lavagem e forma de secagem;

- Características do uso de absorventes higiênicos na gravidez;

- Características de hábitos de higiene genital, após eliminações vesicointestinais das mulheres e parceiro;

- Características de hábitos sexuais na gravidez;

- Características dos hábitos de higiene, antes e após o coito das mulheres e parceiro;

- Características de sintomas de infecção urinária na gravidez;

- Características de orientações sobre higiene genital no pré-natal.

Um formulário para a coleta de dados foi elaborado e estruturado especificamente para este estudo (Apêndice 3). O instrumento continha perguntas referentes às variáveis estudadas. 


\subsection{COLETA DE DADOS}

O critério adotado consistiu na abordagem de todas as puérperas que estavam presentes nos dias em que a autora desta pesquisa, que realizou toda a coleta, compareceu à Instituição para esta finalidade. Isto ocorreu em dias alternados, inclusive, nos finais de semana.

A obtenção dos dados foi feita mediante a entrega dos formulários para as puérperas, após o rapport estabelecido para explicação dos aspectos éticos. Tomou-se o cuidado de abordar as puérperas somente a partir do segundo dia após o parto, em respeito às condições físicas delas. Acreditase que nesse período após o parto, as puérperas estejam restabelecidas do cansaço provocado pelo parto. Não houve recusa para colaborar neste estudo.

Quanto à ocorrência da ITU na gravidez, havia o planejamento para obtenção deste dado no prontuário ou no cartão do pré-natal. Constatou-se, entretanto, que este dado não constava do prontuário e a maioria das puérperas não havia trazido o cartão do pré-natal. Diante da dificuldade, solicitou-se que as puérperas autorreferissem a ocorrência da ITU na gravidez e seus sintomas.

Os dados foram coletados com 220 puérperas ( $\mathrm{N}=220)$, à beira do leito ou em uma sala do setor reservada para entrevistas individuais, no alojamento conjunto da Instituição. O tempo de preenchimento do formulário pelas puérperas variou entre 15 e 30 minutos. Para algumas, houve a necessidade da pesquisadora fazer a leitura do formulário e o respectivo preenchimento, em razão da ausência ou pouca escolaridade das puérperas.

\subsection{TRATAMENTO DOS DADOS}

Os dados contidos no instrumento foram introduzidos em dois bancos de dados do Epi Info versão 6, elaborado exclusivamente para esta pesquisa. O processo denominado "validate" foi realizado para a verificação da existência de erros de digitação, sendo possível, mediante o duplo 
registro dos dados. Considerou-se o banco de dados pronto para análise quando não houve discordância entre os dois bancos de dados.

A seguir, foi realizada a análise estatística dos dados, mediante a utilização do programa estatístico Statistical Package for Social Sciences (SPSS) for Windows versão 12.0.

A caracterização da amostra foi feita por meio de frequência absoluta e relativa. A associação entre a ocorrência da infecção urinária e as variáveis independentes foi feita pelo teste Qui-quadrado com correções de continuidade. Em todas as análises, considerou-se significativo quando $p<$ 0,05 . Esta análise e todas as demais fases da pesquisa que possuíam relação com o tratamento dos dados foram desenvolvidas, mediante assessoria de uma profissional em estatística. 
RESULTADOS

- 


\section{RESULTADOS}

Os resultados deste estudo estão apresentados em forma de tópicos, expostos a seguir.

\subsection{CARACTERIZAÇÃO DA AMOSTRA}

As características sociodemográficas das puérperas estão na Tabela 1.

Tabela 1 - Características sociodemográficas das puérperas, São Paulo, 2008.

\begin{tabular}{|c|c|c|c|}
\hline Variáveis & Categorias & $\mathbf{N}$ & $\%$ \\
\hline \multirow[t]{4}{*}{ Naturalidade } & São Paulo & 139 & 63,0 \\
\hline & Outros estados & 41 & 18,8 \\
\hline & Outros países & 05 & 2,3 \\
\hline & Ignorado & 35 & 15,9 \\
\hline Idade & Até 19 & 43 & 19,5 \\
\hline \multirow[t]{2}{*}{ (anos) } & $20-29$ & 114 & 51,8 \\
\hline & 30 ou mais & 63 & 28,7 \\
\hline \multirow[t]{4}{*}{ Escolaridade } & Nenhum & 04 & 1,8 \\
\hline & Ensino fundamental & 94 & 42,7 \\
\hline & Ensino médio & 102 & 46,4 \\
\hline & Ensino superior & 20 & 9,1 \\
\hline \multirow[t]{2}{*}{ Trabalho } & No próprio lar & 138 & 62,7 \\
\hline & Remunerado & 82 & 37,3 \\
\hline \multirow[t]{4}{*}{ Religião } & Católica & 107 & 48,7 \\
\hline & Evangélica & 75 & 34,1 \\
\hline & Não possui & 17 & 7,7 \\
\hline & Outras & 21 & 9,5 \\
\hline Total & & 220 & 100,0 \\
\hline
\end{tabular}

Os dados da Tabela 1 demonstram que a maioria $(63,0 \%)$ das puérperas nasceu no Estado de São Paulo. A idade variou entre 14 e 43 
anos, com maior concentração de mulheres na faixa etária de 20 a 29 anos $(51,8 \%)$. A escolaridade variou entre nenhum até o ensino superior completo. A maior proporção de mulheres $(42,7 \%)$ concluiu o ensino fundamental e 46,4\%, o ensino médio. A frequência de puérperas que trabalhava no próprio lar foi de 62,7\%. Quanto à religião, a maior proporção $(48,7 \%)$ era católica, seguida pelas evangélicas (34,1\%), 9,5\% tinham outras religiões, dentre elas o espiritismo e o budismo e 7,7\% não tinham religião.

As características sociodemográficas dos parceiros estão na Tabela 2.

Tabela 2 - Características sociodemográficas dos parceiros. São Paulo, 2008.

\begin{tabular}{llcc}
\hline \multicolumn{1}{c}{ Variáveis } & \multicolumn{1}{c}{ Categorias } & N & $\%$ \\
\hline \multirow{2}{*}{ Idade } & Até 19 & 14 & 6,3 \\
& $20-29$ & 122 & 55,5 \\
& 30 ou mais & 84 & 38,2 \\
Escolaridade & & & \\
& Nenhum & 05 & 2,3 \\
& Ensino fundamental & 98 & 44,6 \\
& Ensino médio & 91 & 41,3 \\
& Ensino superior & 21 & 9,5 \\
& Ignorado & 05 & 2,3 \\
Religião & & & \\
& & & \\
& Católica & 112 & 50,9 \\
& Evangélica & 47 & 21,3 \\
& Não possui & 40 & 18,3 \\
& Outras & 21 & 9,5 \\
Participação no pré-natal & Nunca & & \\
(Número de consultas) & De 01 a 03 & 102 & 46,4 \\
& 04 ou mais & 74 & 33,6 \\
& & 44 & 20,0 \\
\hline Total & & 220 & 100,0 \\
\hline
\end{tabular}

Os dados da Tabela 2 demonstram que a idade dos parceiros variou entre 17 e 53 anos e a maioria (55,5\%) estava na faixa etária de 20 a 29 anos. A escolaridade variou entre nenhum (2,3\%) até o ensino superior completo (9,5\%). A maior proporção de parceiros $(44,6 \%)$ concluiu o ensino 
fundamental e 41,3\%, o ensino médio. Quanto à religião, a maior proporção $(50,9 \%)$ era católica, seguida pela evangélica (21,3\%). A proporção de parceiros que não possuía religião foi de $18,3 \%$ e os que tinham outras religiões foi de $9,5 \%$.

Quanto à participação dos parceiros durante o pré-natal segundo o número de consultas, constatou-se que $46,4 \%$ não compareceram em nenhuma consulta, 33,6\% estiveram presentes em uma a três consultas e $20,0 \%$ compareceram a quatro ou mais consultas de pré-natal.

A ocorrência e as características de sintomas e infecção urinária durante a gravidez estão na Tabela 3.

Tabela 3 - Características dos sintomas, ocorrência da ITU na gravidez e tratamento. São Paulo, 2008.

\begin{tabular}{llcc}
\hline \multicolumn{1}{c}{ Variáveis } & \multicolumn{1}{c}{ Categorias } & N & $\%$ \\
\hline \multirow{3}{*}{ Ocorrência de sintomas } & Nenhum & 87 & 39,5 \\
& Dor em baixo ventre & 56 & 25,5 \\
& 2 ou mais sintomas & 41 & 18,5 \\
& Urgência para urinar & 01 & 3,2 \\
& Dor ao urinar & 07 & 3,2 \\
& Febre & 01 & 0,5 \\
& Hematúria & 01 & 0,5 \\
& & & \\
Ocorrência de infecção urinária & Sim & 73 & 33,2 \\
& Não & 133 & 60,4 \\
& Não sabe informar & 14 & 6,4 \\
& & & \\
Ocorrência de tratamento & Não referiram ITU & 147 & 66,8 \\
& Sim & 69 & 31,4 \\
& Não & 04 & 1,8 \\
\hline Total & & 220 & 100,0 \\
\hline
\end{tabular}

Os dados da Tabela 3 demonstram que a maior proporção $(39,5 \%)$ das puérperas não apresentou sintomas de infecção urinária durante a gravidez. No entanto, $25,5 \%$ relataram a ocorrência de dor em baixo ventre e $18,5 \%$ referiram dois ou mais sintomas associados, que foram classificados como dor ao urinar e urgência, dor ao urinar e dor em baixo ventre, urgência para 
urinar e dor em baixo ventre, urgência para urinar e dor em baixo ventre, urgência para urinar e febre, dor em baixo ventre e febre.

A maioria $(60,4 \%)$ das puérperas não referiu infecção urinária e $(33,2 \%)$ relatou a ocorrência de infecção urinária durante a gravidez.

Dessas 73 (33,2\%) puérperas que referiram ITU, 69 relataram a realização do tratamento com antibioticoterapia.

As características de tipo de parto, participação no pré-natal e paridade das puérperas estão na Tabela 4.

Tabela 4- Características do pré-natal, paridade e tipo de parto das puérperas. São Paulo, 2008.

\begin{tabular}{|c|c|c|c|}
\hline Variáveis & Categorias & $\mathbf{N}$ & $\%$ \\
\hline \multirow[t]{3}{*}{ Tipo de parto } & Parto Normal & 140 & 63,7 \\
\hline & Parto Cesárea & 72 & 32,7 \\
\hline & Parto Fórcipe & 08 & 3,6 \\
\hline \multirow[t]{3}{*}{ Pré-natal } & Não realizou pré-natal & 15 & 6,8 \\
\hline & Realizou até 06 consultas & 71 & 32,3 \\
\hline & 7 ou mais consultas & 134 & 60,9 \\
\hline \multirow[t]{4}{*}{ Local do pré-natal } & Não realizou & 15 & 6,8 \\
\hline & Serviço público & 178 & 80,9 \\
\hline & Médico do convênio ou particular & 14 & 6,4 \\
\hline & Local não informado & 13 & 5,9 \\
\hline \multirow{2}{*}{$\begin{array}{l}\text { Grupo de orientação } \\
\text { (Participação) }\end{array}$} & Sim & 34 & 15,5 \\
\hline & Não & 186 & 84,5 \\
\hline \multirow[t]{2}{*}{ Filho(s) anterior(es) } & Sim & 132 & 60,0 \\
\hline & Não & 88 & 40,0 \\
\hline \multirow[t]{5}{*}{ Parto(s) anterior(es) } & Não teve & 88 & 40,0 \\
\hline & Parto Normal & 71 & 33,3 \\
\hline & Parto Cesárea & 38 & 17,2 \\
\hline & Parto Fórcipe & 05 & 2,3 \\
\hline & Partos associados* & 18 & 7,2 \\
\hline Total & & 220 & 100,0 \\
\hline
\end{tabular}


Os dados da Tabela 4 demonstram que a maioria $(63,7 \%)$ das puérperas teve parto normal, seguido de parto cesárea $(32,7 \%)$ e fórcipe (3,6\%). A realização de consultas de pré-natal variou entre nenhuma até sete ou mais consultas. A maior proporção de puérperas $(60,9 \%)$ realizou sete ou mais consultas, 32,3\% participaram de até 06 consultas de pré-natal. A frequência das puérperas que realizaram pré-natal em serviço público foi 80,9\%. Quanto à participação de grupo de orientação às gestantes, a maior proporção (84,5\%) não participou desse tipo de atividade. A maioria das puérperas $(60,0 \%)$ já possuía filho(s) anterior(es) e, dentre elas, 33,3\% tiveram parto normal.

A descrição da disponibilidade de banheiros está na Tabela 5.

Tabela 5 - Existência de banheiro no domicílio e no local de trabalho das puérperas. São Paulo, 2008.

\begin{tabular}{llcc}
\hline \multicolumn{1}{c}{ Variáveis } & Categorias & $\mathbf{N}$ & $\%$ \\
\hline \multirow{2}{*}{ Banheiro na residência } & Sim & 175 & 79,5 \\
& Não & 45 & 20,5 \\
& & & \\
Banheiro exclusivo para o casal & Sim & 137 & 62,3 \\
& Não & 83 & 37,7 \\
Banheiro no trabalho & & & \\
& Sim & 38 & 17,3 \\
& Não & 44 & 20,0 \\
& Não trabalha & 138 & 62,7 \\
\hline Total & & & \\
\hline
\end{tabular}

Os dados da Tabela 5 demonstram que a maioria $(79,5 \%)$ das puérperas possuía banheiro na residência e as que referiram ter banheiro privativo na residência para uso privativo do casal foi de 62,3\%. Quase metade das puérperas não tinha trabalho remunerado (46,8\%) e 17,3\% dentre aquelas que trabalhavam, tinham banheiro no trabalho. Na maioria das residências, tinha banheiro com chuveiro $(99,5 \%)$, com pia $(89,0 \%)$ e em apenas trinta residências havia bidê (13,6\%). Analisando as oitenta e duas 
mulheres que trabalhavam com remuneração, verificou-se que em $72,0 \%$ das residências havia chuveiro no banheiro e em $11,0 \%$ delas, bidê.

As características da higienização das roupas íntimas das puérperas estão na Tabela 6 .

Tabela 6 - Características da higienização das roupas íntimas das puérperas. São Paulo, 2008.

\begin{tabular}{llcc}
\hline \multicolumn{1}{c}{ Variáveis } & \multicolumn{1}{c}{ Categorias } & N & $\%$ \\
\hline \multirow{2}{*}{ Produto utilizado } & \multicolumn{1}{c}{ Sabonete } & 68 & 30,9 \\
& Sabão em pedra & 31 & 14,1 \\
& Sabão em pó & 121 & 55,0 \\
& & & \\
Forma de lavagem & Lavagem à mão & 136 & 61,8 \\
& Lavagem à máquina & 84 & 38,2 \\
& & & \\
Forma de secagem & Local com sol & 154 & 70,0 \\
& Dentro do banheiro & 09 & 4,1 \\
& Local sem sol & 53 & 24,1 \\
& Secadora & 04 & 1,8 \\
& & & \\
\hline Total & & 220 & 100,0 \\
\hline
\end{tabular}

Os dados da Tabela 6 demonstram que a maioria $(55,0 \%)$ das puérperas utiliza o sabão em pó para lavar as roupas íntimas. A maior proporção $(61,8 \%)$ lava as roupas íntimas à mão e a maior proporção $(70,0 \%)$ seca as roupas em local onde há presença de luz solar.

As características da higienização das roupas íntimas das puérperas estão na Tabela 7. 
Tabela 7 - Uso de absorventes na gravidez. São Paulo, 2008. N=220.

\begin{tabular}{llcc}
\hline \multicolumn{1}{c}{ Variáveis } & Categorias & N & $\%$ \\
\hline \multirow{2}{*}{ Absorvente externo } & Sim & 57 & \\
& Não & 163 & 74,9 \\
& & & \\
Absorvente interno & Sim & 03 & 1,4 \\
& Não & 217 & 98,6 \\
\hline Total & & 220 & 100,0 \\
\hline
\end{tabular}

Os dados da Tabela 7 demonstram que a maioria $(74,1 \%)$ das puérperas não utilizou absorvente externo e também não usou absorvente interno $(98,6 \%)$ durante o período gestacional.

As características de hábitos de higiene genital das puérperas após eliminações vesicoinstestinais estão na Tabela 8.

Tabela 8 - Hábitos de higiene genital após eliminações vesicointestinais na gravidez. São Paulo, 2008.

\begin{tabular}{llcc}
\hline \multicolumn{1}{c}{ Variáveis } & \multicolumn{1}{c}{ Categorias } & N & $\%$ \\
\hline \multirow{3}{*}{ Após micção } & 03 & 1,4 \\
& Não realiza higiene & 85 & 38,6 \\
& Limpa com papel higiênico ou lenços umedecidos & 91 & 41,4 \\
& Limpa com papel higiênico de frente para trás & 34 & 15,4 \\
& Limpa com papel higiênico de trás para frente & 07 & 3,2 \\
& Lava a região genital com água e sabonete & & \\
& & & \\
\multirow{4}{*}{ Após evacuação } & Não realiza higiene & 02 & 0,9 \\
& Limpa com papel higiênico ou lenços umedecidos & 75 & 34,1 \\
& Limpa com papel higiênico de frente para trás & 111 & 50,5 \\
& Limpa com papel higiênico de trás para frente & 17 & 7,7 \\
& Lava a região anal com água e sabonete & 15 & 6,8 \\
& & & \\
\hline Total & & 220 & 100,0 \\
\hline
\end{tabular}

Os dados da Tabela 8 demonstram que $41,4 \%$ das puérperas se higienizava após a micção, limpando-se com papel higiênico com movimentos de frente para trás e $(38,6 \%)$ limpava com papel higiênico ou lenço umedecido sem atentar para sentido dos movimentos de higiene. A 
maior proporção de mulheres (50,5\%) higienizava após evacuação, limpando com papel higiênico ou lenço umedecido com movimentos de frente para trás.

As características de hábitos de higiene genital dos parceiros, após eliminações vesicoinstestinais estão na Tabela 9.

Tabela 9 - Hábitos de higiene genital após eliminações vesicointestinais dos parceiros. São Paulo, 2008.

\begin{tabular}{llcc}
\hline \multicolumn{1}{c}{ Variáveis } & \multicolumn{1}{c}{ Categorias } & N & $\%$ \\
\hline \multirow{3}{*}{ Após micção } & 88 & 40,0 \\
& Não realiza higiene & 65 & 29,5 \\
& Limpa com papel higiênico ou lenços umedecidos & 36 & 16,3 \\
& Lava o pênis com água e sabonete & 31 & 14,2 \\
& Não sabe & & \\
\cline { 2 - 4 } Após evacuação & Não sabe informar & 36 & 16,4 \\
& Limpa com papel higiênico ou lenços umedecidos & 73 & 33,1 \\
& Limpa com papel higiênico de frente para trás & 70 & 31,8 \\
& Limpa com papel higiênico de trás para frente & 11 & 5,0 \\
& Lava a região anal com água e sabonete & 30 & 13,7 \\
& & & \\
\hline Total & & 220 & 100,0 \\
\hline
\end{tabular}

Os dados da Tabela 9 demonstram que $(40,0 \%)$ dos parceiros não realizava nenhum tipo de higiene após a micção e $(29,5 \%)$ limpava o pênis com papel higiênico ou lenço umedecido após urinar. Cerca de um terço $(31,8 \%)$ dos parceiros limpava com papel higiênico com movimentos de frente para trás após evacuar e $(33,1 \%)$ dos parceiros limpava com papel higiênico ou lenço umedecido sem atentar para o sentido dos movimentos de higiene após evacuação.

As características dos hábitos sexuais das puérperas estão na Tabela 10. 
Tabela 10 - Hábitos sexuais das puérperas durante a gravidez. São Paulo, 2008.

\begin{tabular}{llcc}
\hline \multicolumn{1}{c}{ Variáveis } & \multicolumn{1}{c}{ Categorias } & N & $\%$ \\
\hline \multirow{3}{*}{ Número de parceiro(s) } & Nenhum & 14 & 6,4 \\
& 01 & 202 & 91,8 \\
& 02 ou mais & 04 & 1,8 \\
& & & \\
& & & \\
Tipo de relação & Vaginal & 180 & 81,9 \\
& Vaginal e anal & 08 & 3,6 \\
& Nenhum & 32 & 14,5 \\
& & & \\
Frequência & Diária & 25 & 11,3 \\
& Semanal & 106 & 48,3 \\
& Quinzenal & 19 & 8,6 \\
& Mensal & 38 & 17,3 \\
& Não teve & 32 & 14,5 \\
\hline Total & & 220 & 100,0 \\
\hline
\end{tabular}

* Classificou-se como frequência semanal: um, dois ou três vezes de relação sexual por semana.

Os dados da Tabela 10 demonstram que a maioria $(91,8 \%)$ das puérperas teve apenas um parceiro sexual durante a gravidez. A maior proporção de puérperas $(81,9 \%)$ manteve relação do tipo vaginal e para $48,3 \%$, a frequência de atividade sexual era semanal.

As características dos hábitos de higiene genital das puérperas antes e após o coito sexual estão na Tabela 11.

Tabela 11 - Hábitos de higiene das puérperas antes e após o coito na gravidez. São Paulo, 2008.

\begin{tabular}{llcc}
\hline \multicolumn{1}{c}{ Variáveis } & \multicolumn{1}{c}{ Categorias } & N & $\%$ \\
\hline \multirow{2}{*}{ Hábitos antes } & & \\
& & 28 & 12,7 \\
& Não realizou & 58 & 26,4 \\
& Lavou a região genital com água e sabonete & 134 & 60,9 \\
& Tomou banho de chuveiro & & \\
& & & \\
Hábito após & Não realizou & 04 & 1,8 \\
& Lavou a região genital com água e sabonete & 49 & 22,3 \\
& Tomou banho de chuveiro & 167 & 75,9 \\
\hline Total & & 220 & 100,0 \\
\hline
\end{tabular}


Os dados da Tabela 11 demonstram que a maioria $(60,9 \%)$ das puérperas tomava banho de chuveiro antes da relação sexual e a maior proporção $(75,9 \%)$ de puérperas tomava banho de chuveiro depois do coito.

As características dos hábitos de higiene genital dos parceiros antes e após o coito sexual estão na Tabela 12.

Tabela 12 - Hábitos de higiene dos parceiros antes e após o coito na gravidez. São Paulo, 2008.

\begin{tabular}{llcc}
\hline \multicolumn{1}{c}{ Variáveis } & \multicolumn{1}{c}{ Categorias } & N & $\%$ \\
\hline \multirow{3}{*}{ Hábito antes } & & \\
& Não realizou & 38 & 17,2 \\
& Lavou o pênis com água e sabonete & 58 & 26,3 \\
& Tomou banho de chuveiro & 100 & 45,4 \\
& Não sabe & 24 & 10,9 \\
& & & \\
Hábito após & Não realizou & 06 & 2,7 \\
& Lavou o pênis com água e sabonete & 61 & 27,7 \\
& Tomou banho de chuveiro & 129 & 58,7 \\
& Não sabe & 24 & 10,9 \\
\hline Total & & 220 & 100,0 \\
\hline
\end{tabular}

Os dados da Tabela 12 demonstram que a proporção de $(45,4 \%)$ dos parceiros tomava banho de chuveiro antes da relação sexual, seguidos de $(26,3 \%)$ que lavava o pênis com água e sabonete e uma pequena proporção $(17,2 \%)$ de parceiros não realizava nenhum tipo de higiene antes da relação sexual. A maior proporção $(58,7 \%)$ de parceiros tomava banho de chuveiro depois do ato sexual, seguido $(27,7 \%)$ de parceiros que lavava o pênis com água e sabonete após o coito.

A ocorrência e as características de sintomas e infecção urinária autorreferidas durante a gravidez estão na Tabela 13. 
Tabela 13 - Existência de orientações sobre higiene genital na assistência pré-natal. São Paulo, 2008.

\begin{tabular}{lllc}
\hline \multicolumn{1}{c}{ Variáveis } & Categorias & N & $\%$ \\
\hline & & & \\
Existência de orientação para a gestante & Não & 186 & 84,5 \\
& Sim & 34 & 15,5 \\
Profissional orientou a gestante & & & \\
& Médico & 19 & 8,7 \\
& Não sabe & 15 & 6,8 \\
& Não houve & 186 & 84,5 \\
Existência de orientação para o parceiro & & & \\
& Não & 212 & 96,3 \\
& Sim & 07 & 3,2 \\
& Não sabe & 01 & 0,5 \\
Profissional que orientou o parceiro & & & \\
& Médico & 03 & 1,4 \\
& Não sabe & 04 & 1,9 \\
& Não houve & 213 & 96,7 \\
\hline Total & & & \\
\hline
\end{tabular}

Os dados da Tabela 13 demonstram que a maior proporção $(84,5 \%)$ puérperas não foi orientada a respeito de higiene genital durante o pré-natal e uma pequena proporção (15,5\%) recebeu informações sobre como prevenir a infecção urinária e hábitos de higiene genital na gravidez. Dentre as 34 puérperas que receberam informações na gravidez, 55,9\% referiram que o profissional que realizou a orientação foi o médico. A maioria $(96,3 \%)$ dos parceiros também não recebeu informações sobre hábitos de higiene genital.

\subsection{ASSOCIAÇÃO ENTRE OCORRÊNCIA DA ITU E AS CARACTERÍSTICAS SOCIODEMOGRÁFICAS DA PUÉRPERA E DO PARCEIRO}

Não houve associação significativa entre a presença de infecção urinária e a idade da puérpera $(p=0,340)$, escolaridade $(p=0,735)$, 
naturalidade $(p=0,575)$, religião $(p=0,322)$ e trabalho $(p=0,122)$. (Tabela 14)

Tabela 14- Características sociodemográficas das puérperas, segundo ocorrência da ITU na gravidez. São Paulo, 2008.

\begin{tabular}{|c|c|c|c|c|c|}
\hline \multirow[t]{2}{*}{ Variáveis } & \multirow[t]{2}{*}{ Categorias } & \multicolumn{2}{|c|}{ ITU } & \multirow{2}{*}{$\begin{array}{l}\text { TOTAL } \\
\text { N (\%) }\end{array}$} & \multirow[t]{2}{*}{$\mathbf{p}^{*}$} \\
\hline & & $\begin{array}{l}\text { NÃO } \\
\text { N (\%) }\end{array}$ & $\begin{array}{r}\text { SIM } \\
\mathbf{N}(\%) \\
\end{array}$ & & \\
\hline \multirow[t]{3}{*}{ Idade } & Até 19 & $22(51,2)$ & $21(48,8)$ & $43(100,0)$ & 0,340 \\
\hline & $20-29$ & $70(61,4)$ & $44(38,6)$ & $114(100,0)$ & \\
\hline & 30 ou mais & $41(65,1)$ & $22(39,5)$ & $63(100,0)$ & \\
\hline \multirow[t]{3}{*}{ Escolaridade } & Ensino fundamental & $62(63,3)$ & $36(36,7)$ & $98(100,0)$ & 0,735 \\
\hline & Ensino médio & $59(57,8)$ & $43(42,2)$ & $102(100,0)$ & \\
\hline & Ensino superior & $12(60,0)$ & $08(40,0)$ & $20(100,0)$ & \\
\hline \multirow[t]{3}{*}{ Naturalidade } & São Paulo & $81(58,3)$ & $58(41,7)$ & $139(100,0)$ & 0,575 \\
\hline & Outros estados & $26(63,4)$ & $15(36,6)$ & $41(100,0)$ & \\
\hline & Outros países & $02(40,0)$ & $03(60,0)$ & $05(100,0)$ & \\
\hline \multirow[t]{4}{*}{ Religião } & Católica & $62(57,9)$ & $45(42,1)$ & $107(100,0)$ & 0,322 \\
\hline & Evangélica & $43(57,3)$ & $32(42,7)$ & $75(100,0)$ & \\
\hline & Não possui & $12(70,6)$ & $05(29,4)$ & $17(100,0)$ & \\
\hline & Outras & $16(76,2)$ & $05(23,8)$ & $21(100,0)$ & \\
\hline \multirow[t]{2}{*}{ Trabalho } & No próprio lar & $78(56,5)$ & $60(43,5)$ & $138(100,0)$ & 0,122 \\
\hline & Remunerado & $55(67,1)$ & $27(32,9)$ & $82(100,0)$ & \\
\hline
\end{tabular}

p*: Teste de associação pelo Qui-quadrado.

Não houve associação significativa entre a presença de infecção urinária e a idade do parceiro $(p=0,605)$, escolaridade $(p=0,123)$, religião $(p=0,322)$ e participação do parceiro nas consultas do pré-natal $(p=0,074)$ (Tabela 15). 
Tabela 15- Características sociodemográficas dos parceiros, segundo ocorrência da ITU autorreferida na gravidez. São Paulo, 2008.

\begin{tabular}{|c|c|c|c|c|c|}
\hline \multirow[t]{2}{*}{ Variáveis } & \multirow[t]{2}{*}{ Categorias } & \multicolumn{2}{|c|}{ ITU } & \multirow{2}{*}{$\begin{array}{c}\text { TOTAL } \\
\text { N (\%) }\end{array}$} & \multirow[t]{2}{*}{$p^{*}$} \\
\hline & & $\begin{array}{r}\text { NÃO } \\
\text { N (\%) }\end{array}$ & $\begin{array}{l}\text { SIM } \\
\text { N (\%) }\end{array}$ & & \\
\hline \multirow[t]{3}{*}{ Idade } & Até 19 & $11(68,8)$ & $03(31,2)$ & $14(100,0)$ & 0,605 \\
\hline & $20-29$ & $72(58,3)$ & $50(41,7)$ & $122(100,0)$ & \\
\hline & 30 ou mais & $52(61,9)$ & $32(38,1)$ & $84(100,0)$ & \\
\hline \multirow[t]{3}{*}{ Escolaridade } & Ensino & $70(68,0)$ & $33(32,0)$ & $103(100,0)$ & 0,123 \\
\hline & fundamental & $49(53,8)$ & $42(46,2)$ & $91(100,0)$ & \\
\hline & Ensino médio & $12(57,1)$ & $09(42,9)$ & $21(100,0)$ & \\
\hline \multirow[t]{4}{*}{ Religião } & Católica & $66(58,9)$ & $46(41,1)$ & $112(100,0)$ & 0,322 \\
\hline & Evangélica & $24(51,1)$ & $23(48,9)$ & $47(100,0)$ & \\
\hline & Não possui & $30(75,0)$ & $10(25,0)$ & $40(100,0)$ & \\
\hline & Outras & $13(61,9)$ & $08(38,1)$ & $21(100,0)$ & \\
\hline \multirow[t]{3}{*}{ Participação pré-natal } & Nunca & $65(63,7)$ & $37(36,3)$ & $102(100,0)$ & 0,074 \\
\hline & De 1 a 3 & $48(64,9)$ & $26(35,1)$ & $74(100,0)$ & \\
\hline & Todas & $20(45,5)$ & $24(54,4)$ & $44(100,0)$ & \\
\hline
\end{tabular}

p*: Teste de associação pelo Qui-quadrado.

\subsection{ASSOCIAÇÃO ENTRE OCORRÊNCIA DE INFECÇÃO DO TRATO} URINÁRIO E AS CARACTERÍSTICAS DO TIPO DE PARTO, PRÉNATAL E PARIDADE

Não houve associação significativa entre a presença de infecção urinária e tipo de parto $(p=0,574)$, realização de pré-natal $(p=0,558)$, local de pré-natal $(p=0,222)$, participação de grupo de orientação $(p=0,581)$, filhos $(p=0143)$ e partos anteriores $(p=0,135)$ (Tabela 16). 
Tabela 16 - Características do pré-natal, paridade e tipo de parto anterior, segundo a ocorrência da ITU autorreferida na gravidez. São Paulo, 2008.

\begin{tabular}{|c|c|c|c|c|c|}
\hline \multirow[t]{2}{*}{ Variáveis } & \multirow[t]{2}{*}{ Categorias } & \multicolumn{2}{|c|}{ ITU } & \multirow{2}{*}{$\begin{array}{c}\text { TOTAL } \\
\text { N (\%) }\end{array}$} & \multirow[t]{2}{*}{$\mathbf{p}^{*}$} \\
\hline & & $\begin{array}{l}\text { NÃO } \\
\text { N (\%) } \\
\end{array}$ & $\begin{array}{r}\text { SIM } \\
\text { N (\%) } \\
\end{array}$ & & \\
\hline \multirow[t]{3}{*}{ Pré-natal } & Não realizou pré-natal & $11(73,3)$ & $04(26,7)$ & $15(100,0)$ & 0,558 \\
\hline & Realizou até 6 consultas & $43(60,6)$ & $28(39,4)$ & $71(100,0)$ & \\
\hline & 7 ou mais consultas & $79(59,0)$ & $55(41,0)$ & $134(100,0)$ & \\
\hline \multirow[t]{4}{*}{ Local de pré-natal } & Não realizou & $11(73,3)$ & $04(26,7)$ & $15(100,0)$ & 0,222 \\
\hline & Serviço público & $106(59,6)$ & $72(40,4)$ & $178(100,0)$ & \\
\hline & Médico do convênio/particular & $06(42,9)$ & $08(57,1)$ & $14(100,0)$ & \\
\hline & Local não informado & $10(76,9)$ & $03(23,1)$ & $13(100,0)$ & \\
\hline \multirow[t]{2}{*}{ Grupo de orientação } & Não & $111(59,7)$ & $75(40,3)$ & $186(100,0)$ & 0,581 \\
\hline & $\operatorname{Sim}$ & $22(64,7)$ & $12(35,3)$ & $34(100,0)$ & \\
\hline \multirow[t]{2}{*}{ Filho(s) anterior(es) } & Não & $48(54,5)$ & $40(45,5)$ & $88(100,0)$ & 0,143 \\
\hline & Sim & $85(64,4)$ & $47(35,6)$ & $132(100,0)$ & \\
\hline \multirow[t]{5}{*}{ Parto(s) anterior(es) } & Não teve & $48(54,5)$ & $40(45,5)$ & $88(100,0)$ & 0,135 \\
\hline & Parto Normal & $45(63,4)$ & $26(36,6)$ & $71(100,0)$ & \\
\hline & Parto Cesárea & $26(68,4)$ & $12(31,6)$ & $38(100,0)$ & \\
\hline & Parto Fórcipe & $01(20,0)$ & $04(80,0)$ & $05(100,0)$ & \\
\hline & Partos associados & $13(72,2)$ & $05(39,5)$ & $18(100,0)$ & \\
\hline \multirow[t]{3}{*}{ Parto atual } & Parto Normal & $81(57,9)$ & $59(42,1)$ & $140(100,0)$ & 0,574 \\
\hline & Parto Cesárea & $47(65,3)$ & $25(34,7)$ & $72(100,0)$ & \\
\hline & Parto Fórcipe & $05(62,5)$ & $03(37,5)$ & $08(100,0)$ & \\
\hline
\end{tabular}

$\mathrm{p}^{*}$ : Teste de associação pelo Qui-quadrado. 


\subsection{ASSOCIAÇÃO ENTRE OCORRÊNCIA DE INFECÇÃO DO TRATO URINÁRIO E A DISPONIBILIDADE DOS BANHEIROS NA RESIDÊNCIA E TRABALHO DA PUÉRPERA}

Não houve associação significativa entre a presença de infecção urinária e banheiro na residência $(p=0,339)$, banheiro exclusivo para o casal $(p=0,235)$ e a presença de banheiro no local de trabalho $(p=0,087)$ (Tabela 17).

Tabela 17 - Existência de banheiro na residência e no trabalho, segundo a ocorrência da ITU na gravidez. São Paulo, 2008.

\begin{tabular}{llrrrr}
\hline \multicolumn{1}{c}{ Variáveis } & Categorias & $\begin{array}{c}\text { NÃO } \\
\text { N (\%) }\end{array}$ & $\begin{array}{r}\text { SIM } \\
\mathbf{N}(\%)\end{array}$ & $\begin{array}{r}\text { TOTAL } \\
\mathbf{N}(\%)\end{array}$ & $\mathbf{p}^{*}$ \\
& & & & & \\
Banheiro na residência & Não & $30(66,7)$ & $15(33,3)$ & $45(100,0)$ & 0,339 \\
& Sim & $103(58,3)$ & $72(41,1)$ & $175(100,0)$ & \\
& & & & & \\
Banheiro exclusivo & Não & $46(55,4)$ & $37(44,6)$ & $83(100,0)$ & 0,235 \\
& Sim & $87(63,5)$ & $50(36,5)$ & $137(100,0)$ & \\
& & & & & \\
Banheiro no trabalho & Não & $22(57,9)$ & $16(42,1)$ & $38(100,0)$ & 0,087 \\
& Sim & $33(75,0)$ & $11(25,0)$ & $44(100,0)$ & \\
& Não trabalha & $78(56,5)$ & $60(43,5)$ & $138(100,0)$ & \\
\hline
\end{tabular}

$\mathrm{p}^{*}$ : Teste de associação pelo Qui-quadrado.

5.5 ASSOCIAÇÃO ENTRE OCORRÊNCIA DE INFECÇÃO DO TRATO URINÁRIO E AS CARACTERÍSTICAS DA HIGIENIZAÇÃO DAS ROUPAS ÍNTIMAS

Não houve associação significativa entre a presença de infecção urinária e produto utilizado na lavagem $(p=0,533)$, forma de lavagem ( $p=$ $0,613)$ e a forma de secagem ( $p=0,719)$ (Tabela 18). 
Tabela 18 - Características da higienização das roupas íntimas, segundo a ocorrência da ITU na gravidez. São Paulo, 2008.

\begin{tabular}{|c|c|c|c|c|c|}
\hline \multirow[t]{2}{*}{ Variáveis } & \multirow[t]{2}{*}{ Categorias } & \multicolumn{2}{|c|}{ ITU } & \multirow{2}{*}{$\begin{array}{c}\text { TOTAL } \\
\text { N (\%) }\end{array}$} & \multirow[t]{2}{*}{$\mathbf{p}^{*}$} \\
\hline & & $\begin{array}{r}\text { NÃO } \\
\text { N (\%) }\end{array}$ & $\begin{array}{c}\text { SIM } \\
\text { N (\%) }\end{array}$ & & \\
\hline \multirow[t]{3}{*}{ Produto utilizado } & Sabonete & $43(63,2)$ & $25(36,8)$ & $68(100,0)$ & 0,533 \\
\hline & Sabão em pedra & $16(51,6)$ & $15(48,4)$ & $31(100,0)$ & \\
\hline & Sabão em pó & $74(61,2)$ & $47(38,8)$ & $121(100,0)$ & \\
\hline \multirow[t]{2}{*}{ Forma de lavagem } & Lavagem à mão & $84(61,8)$ & $52(38,2)$ & $136(100,0)$ & 0,613 \\
\hline & Lavagem à máquina & $49(58,3)$ & $35(41,7)$ & $84(100,0)$ & \\
\hline \multirow[t]{4}{*}{ Forma de secagem } & Local com sol & $94(61,0)$ & $60(39,0)$ & $154(100,0)$ & 0,719 \\
\hline & Local sem sol & $32(60,4)$ & $21(39,6)$ & $53(100,0)$ & \\
\hline & Dentro do banheiro & $04(44,4)$ & $05(55,6)$ & $09(100,0)$ & \\
\hline & Secadora & $03(75,0)$ & $01(25,0)$ & $04(100,0)$ & \\
\hline
\end{tabular}

p*: Teste de associação pelo Qui-quadrado.

\subsection{ASSOCIAÇÃO ENTRE OCORRÊNCIA DE INFECÇÃO DO TRATO URINÁRIO E CARACTERÍSTICAS DO USO DE ABSORVENTE NA GRAVIDEZ}

Não houve associação significativa entre a presença de infecção urinária e o uso de absorvente externo $(p=0,161)$ e absorvente interno $(p=$ 0,825) (Tabela 19).

Tabela 19 - Uso de absorvente higiênico, segundo a ocorrência da ITU na gravidez. São Paulo, 2008.

\begin{tabular}{|c|c|c|c|c|c|}
\hline \multirow[t]{2}{*}{ Variáveis } & \multirow[t]{2}{*}{ Categorias } & \multicolumn{2}{|c|}{ ITU } & \multirow{2}{*}{$\begin{array}{c}\text { TOTAL } \\
\text { N (\%) }\end{array}$} & \multirow[t]{2}{*}{$\mathbf{p}^{*}$} \\
\hline & & $\begin{array}{l}\text { NÃO } \\
\text { N (\%) }\end{array}$ & $\begin{array}{l}\text { SIM } \\
\text { N (\%) }\end{array}$ & & \\
\hline \multirow[t]{2}{*}{ Absorvente externo } & Não & $103(63,2)$ & $60(36,8)$ & $163(100,0)$ & 0,161 \\
\hline & Sim & $30(52,6)$ & $27(47,7)$ & $57(100,0)$ & \\
\hline \multirow[t]{2}{*}{ Absorvente interno } & Não & $131(60,4)$ & $86(39,6)$ & $217(100,0)$ & 0,825 \\
\hline & Sim & $02(66,7)$ & $01(33,3)$ & $03(100,0)$ & \\
\hline
\end{tabular}

p*: Teste de associação pelo Qui-quadrado. 


\subsection{ASSOCIAÇÃO ENTRE OCORRÊNCIA DE INFECÇÃO DO TRATO URINÁRIO E AS CARACTERÍSTICAS DE PRÁTICAS DE HIGIENE GENITAL}

Não houve associação significativa entre a presença de infecção urinária e hábitos de higiene da puérpera após urinar $(p=0,829)$ ou após evacuar $(p=0,642)$ (Tabela 20).

Tabela 20 - Hábitos de higiene genital após eliminações vesicointestinais das puérperas, segundo a ocorrência da ITU na gravidez. São Paulo, 2008.

\begin{tabular}{|c|c|c|c|c|c|}
\hline \multirow[t]{2}{*}{ Variáveis } & \multirow[t]{2}{*}{ Categorias } & \multicolumn{2}{|c|}{ ITU } & \multirow{2}{*}{$\begin{array}{c}\text { TOTAL } \\
\text { N (\%) }\end{array}$} & \multirow[t]{2}{*}{$\mathbf{p}^{*}$} \\
\hline & & $\begin{array}{r}\text { NÃO } \\
\text { N (\%) } \\
\end{array}$ & $\begin{array}{c}\text { SIM } \\
\text { N (\%) }\end{array}$ & & \\
\hline \multirow[t]{5}{*}{ Após urinar } & Não realiza & $02(66,7)$ & $01(33,3)$ & $03(100,0)$ & 0,829 \\
\hline & Limpa com papel higiênico & $55(64,7)$ & $30(35,3)$ & $85(100,0)$ & \\
\hline & Com papel higiênico de frente para trás & $51(56,0)$ & $40(44,0)$ & $91(100,0)$ & \\
\hline & Com papel higiênico de trás para frente & $21(61,8)$ & $13(38,2)$ & $34(100,0)$ & \\
\hline & Lava a genitália com água e sabonete & $04(57,1)$ & $03(42,9)$ & $07(100,0)$ & \\
\hline \multirow[t]{5}{*}{ Após evacuar } & Não realiza & $02(100,0)$ & $00(00,0)$ & $02(100,0)$ & 0,642 \\
\hline & Limpa com papel higiênico & $44(58,7)$ & $31(41,3)$ & $75(100,0)$ & \\
\hline & Com papel higiênico de frente para trás & $66(59,5)$ & $45(40,5)$ & $111(100,0)$ & \\
\hline & Com papel higiênico de trás para frente & $10(58,8)$ & $07(41,2)$ & $17(100,0)$ & \\
\hline & Lava a região com água e sabonete & $11(73,3)$ & $04(26,7)$ & $15(100,0)$ & \\
\hline
\end{tabular}

$p^{\star}$ : Teste de associação pelo Qui-quadrado.

Não houve associação significativa entre a presença de infecção urinária e hábitos de higiene do parceiro após urinar $(p=0,378)$ ou após evacuar $(p=0,658)$ (Tabela 21). 
Tabela 21 - Hábitos de higiene genital após eliminações vesicointestinais dos parceiros, segundo a ocorrência da ITU na gravidez. São Paulo, 2008.

\begin{tabular}{|c|c|c|c|c|c|}
\hline \multirow[t]{2}{*}{ Variáveis } & \multirow[t]{2}{*}{ Categorias } & \multicolumn{2}{|c|}{ ITU } & \multirow{2}{*}{$\begin{array}{l}\text { TOTAL } \\
\text { N (\%) }\end{array}$} & \multirow[t]{2}{*}{$\mathbf{p}^{*}$} \\
\hline & & $\begin{array}{l}\text { NÃO } \\
\text { N (\%) }\end{array}$ & $\begin{array}{r}\text { SIM } \\
\mathbf{N}(\%)\end{array}$ & & \\
\hline \multirow{4}{*}{$\begin{array}{l}\text { Após } \\
\text { urinar }\end{array}$} & Não realiza & $47(53,4)$ & $41(46,6)$ & $88(100,0)$ & 0,378 \\
\hline & Limpa o pênis com papel higiênico & $42(64,6)$ & $23(35,4)$ & $65(100,0)$ & \\
\hline & Lava com água e sabonete & $24(66,7)$ & $12(33,3)$ & $36(100,0)$ & \\
\hline & Não sabe/outros & $20(64,5)$ & $11(35,5)$ & $31(100,0)$ & \\
\hline \multirow{5}{*}{$\begin{array}{l}\text { Após } \\
\text { evacuar }\end{array}$} & Limpa com papel higiênico & $45(61,6)$ & $28(38,4)$ & $73(100,0)$ & 0,658 \\
\hline & Com papel higiênico de frente para trás & $38(54,3)$ & $32(45,7)$ & $70(100,0)$ & \\
\hline & Com papel higiênico de trás para frente & $07(63,6)$ & $04(36,4)$ & $11(100,0)$ & \\
\hline & Lava a região com água e sabonete & $18(60,0)$ & $12(40,0)$ & $30(100,0)$ & \\
\hline & Não sabe/outros & $25(69,4)$ & $11(30,6)$ & $36(100,0)$ & \\
\hline
\end{tabular}

$\mathrm{p}^{*}$ : Teste de associação pelo Qui-quadrado.

\subsection{ASSOCIAÇÃO ENTRE OCORRÊNCIA DE INFECÇÃO DO TRATO URINÁRIO E AS CARACTERÍSTICAS DOS HÁBITOS SEXUAIS NA GRAVIDEZ}

Não houve associação significativa entre a presença de infecção urinária e o número de parceiros $(p=0,326)$, tipo de relação sexual ( $p=$ $0,182)$ e a freqüência de relação sexual $(p=0,537)$ (Tabela 22). 
Tabela 22 - Características dos hábitos sexuais, segundo a ocorrência da ITU autorreferida na gravidez. São Paulo, 2008.

\begin{tabular}{|c|c|c|c|c|c|}
\hline \multirow[t]{2}{*}{ Variáveis } & \multirow[t]{2}{*}{ Categorias } & \multicolumn{2}{|c|}{ ITU } & \multirow{2}{*}{$\begin{array}{c}\text { TOTAL } \\
\text { N (\%) }\end{array}$} & \multirow[t]{2}{*}{$\mathbf{p}^{*}$} \\
\hline & & $\begin{array}{l}\text { NÃO } \\
\text { N (\%) }\end{array}$ & $\begin{array}{c}\text { SIM } \\
\text { N (\%) }\end{array}$ & & \\
\hline \multirow[t]{3}{*}{ Número de parceiros } & Nenhum & $06(42,9)$ & $08(57,1)$ & $14(100,0)$ & 0,326 \\
\hline & 1 & $124(61,4)$ & $78(38,6)$ & $202(100,0)$ & \\
\hline & 2 ou mais & $03(75,0)$ & $01(25,0)$ & $04(100,0)$ & \\
\hline \multirow[t]{3}{*}{ Tipo de relação sexual } & Nenhuma & $15(46,9)$ & $17(53,1)$ & $32(100,0)$ & 0,182 \\
\hline & Vaginal & $112(62,2)$ & $68(37,8)$ & $180(100,0)$ & \\
\hline & Vaginal e anal & $06(75,0)$ & $02(25,0)$ & $08(100,0)$ & \\
\hline \multirow{5}{*}{$\begin{array}{l}\text { Frequência } \\
\text { sexual }\end{array}$} & Nenhuma & $15(46,9)$ & $17(53,1)$ & $32(100,0)$ & 0,537 \\
\hline & Diária & $15(60,0)$ & $10(40,0)$ & $25(100,0)$ & \\
\hline & Semanal & $66(62,3)$ & $40(37,7)$ & $106(100,0)$ & \\
\hline & Quinzenal & $12(63,2)$ & $07(36,8)$ & $19(100,0)$ & \\
\hline & Mensal & $25(65,8)$ & $13(34,2)$ & $38(100,0)$ & \\
\hline
\end{tabular}

$\mathrm{p}^{*}$ : Teste de associação pelo Qui-quadrado.

5.9 ASSOCIAÇÃO ENTRE OCORRÊNCIA DE INFECÇÃO DO TRATO URINÁRIO E AS CARACTERÍSTICAS DOS HÁBITOS DE HIGIENE ANTES E APÓS O COITO

Não houve associação significativa entre a presença de infecção urinária e hábitos de higiene da puérpera antes $(p=0,741)$ ou após o coito $(p=0,277)$ (Tabela 23). 
Tabela 23 - Hábitos de higiene genital das puérperas antes e após o coito, segundo a ocorrência da ITU na gravidez. São Paulo, 2008.

\begin{tabular}{|c|c|c|c|c|c|}
\hline \multirow[t]{2}{*}{ Variáveis } & \multirow[t]{2}{*}{ Categorias } & \multicolumn{2}{|c|}{ ITU } & \multirow{2}{*}{$\begin{array}{l}\text { TOTAL } \\
\text { N (\%) }\end{array}$} & \multirow[t]{2}{*}{$\mathbf{p}^{*}$} \\
\hline & & $\begin{array}{l}\text { NÃO } \\
\text { N (\%) }\end{array}$ & $\begin{array}{r}\text { SIM } \\
\mathbf{N}(\%) \\
\end{array}$ & & \\
\hline $\begin{array}{l}\text { Higiene } \\
\text { antes }\end{array}$ & $\begin{array}{l}\text { Não realiza } \\
\text { Lava a genitália com água e sabonete } \\
\text { Toma banho de chuveiro }\end{array}$ & $\begin{array}{l}17(60,7) \\
34(58,6) \\
95(70,9)\end{array}$ & $\begin{array}{l}11(39,3) \\
24(41,4) \\
39(29,1)\end{array}$ & $\begin{array}{l}28(100,0) \\
58(100,0) \\
134(100,0)\end{array}$ & 0,741 \\
\hline $\begin{array}{l}\text { Higiene } \\
\text { após }\end{array}$ & $\begin{array}{l}\text { Não realiza } \\
\text { Lava a genitália com água e sabonete } \\
\text { Toma banho de chuveiro }\end{array}$ & $\begin{array}{l}04(100,0) \\
31(63,3) \\
111(66,4)\end{array}$ & $\begin{array}{l}00(00,0) \\
18(36,7) \\
56(33,6)\end{array}$ & $\begin{array}{l}04(100,0) \\
49(100,0) \\
167(100,0)\end{array}$ & 0,277 \\
\hline
\end{tabular}

Não houve associação significativa entre a presença de infecção urinária e hábitos de higiene do parceiro antes $(p=0,964)$ ou após o coito $(p=$ 0,074) (Tabela 24).

Tabela 24 - Hábitos de higiene genital dos parceiros antes e após o coito, segundo a ocorrência da ITU na gravidez. São Paulo, 2008.

\begin{tabular}{|c|c|c|c|c|c|}
\hline \multirow[t]{2}{*}{ Variáveis } & \multirow[t]{2}{*}{ Categorias } & \multicolumn{2}{|c|}{ ITU } & \multirow{2}{*}{$\begin{array}{l}\text { TOTAL } \\
\text { N (\%) }\end{array}$} & \multirow[t]{2}{*}{$\mathbf{p}^{*}$} \\
\hline & & $\begin{array}{l}\text { NÃO } \\
\text { N (\%) }\end{array}$ & $\begin{array}{r}\text { SIM } \\
\mathbf{N}(\%)\end{array}$ & & \\
\hline \multirow{3}{*}{$\begin{array}{l}\text { Higiene } \\
\text { antes }\end{array}$} & Não realiza & $23(60,5)$ & $15(39,5)$ & $38(100,0)$ & 0,964 \\
\hline & Lava o pênis com água e sabonete & $36(62,1)$ & $22(37,9)$ & $58(100,0)$ & \\
\hline & Toma banho de chuveiro & $63(63,0)$ & $37(37,0)$ & $100(100,0)$ & \\
\hline \multirow[t]{3}{*}{ Higiene após } & Não realiza & $06(100,0)$ & $00(00,0)$ & $06(100,0)$ & 0,074 \\
\hline & Lava o pênis com água e sabonete & $41(67,2)$ & $20(32,8)$ & $61(100,0)$ & \\
\hline & Toma banho de chuveiro & $75(58,1)$ & $54(41,9)$ & $129(100,0)$ & \\
\hline
\end{tabular}

$\mathrm{p}^{*}$ : Teste de associação pelo Qui-quadrado. 
5.10 ASSOCIAÇÃO ENTRE OCORRÊNCIA DE INFECÇÃO DO TRATO URINÁRIO E EXISTÊNCIA DE ORIENTAÇÕES SOBRE HIGIENE GENITAL PARA A PUÉRPERA E SEU PARCEIRO NA GRAVIDEZ

Não houve associação significativa entre a presença de infecção urinária e a existência de orientação sobre higiene genital para a gestante $(p=0,553)$ e orientação para o parceiro $(p=0,162)$ (Tabela 25).

Tabela 25 - Existência de orientação sobre higiene genital para gestantes e parceiros, segundo a ocorrência da ITU na gravidez. São Paulo, 2008.

\begin{tabular}{|c|c|c|c|c|c|}
\hline \multirow[t]{2}{*}{ Variáveis } & \multirow[t]{2}{*}{ Categorias } & \multicolumn{2}{|c|}{ ITU } & \multirow{2}{*}{$\begin{array}{l}\text { TOTAL } \\
\text { N (\%) }\end{array}$} & \multirow[t]{2}{*}{$\mathbf{p}^{*}$} \\
\hline & & $\begin{array}{l}\text { NÃO } \\
\text { N (\%) }\end{array}$ & $\begin{array}{l}\text { SIM } \\
\text { N (\%) }\end{array}$ & & \\
\hline \multirow[t]{2}{*}{ Orientação para a gestante } & Não & $114(61,3)$ & $72(38,7)$ & $186(100,0)$ & 0,553 \\
\hline & Sim & $19(55,9)$ & $15(44,1)$ & $34(100,0)$ & \\
\hline \multirow[t]{2}{*}{ Orientação para o parceiro } & Não & $126(59,4)$ & $86(40,6)$ & $212(100,0)$ & 0,162 \\
\hline & Sim & $06(85,7)$ & $01(14,3)$ & $07(100,0)$ & \\
\hline
\end{tabular}




\section{DISCUSSÃO}

Em relação às características pessoais das puérperas, constatou-se que a maior proporção encontrava-se na faixa etária de 20 a 29 anos, a escolaridade variou entre nenhuma até o ensino superior completo, com maior proporção de mulheres com ensino médio. Quanto à religião, a maioria $(48,7 \%)$ era católica, seguida pelas evangélicas $(34,1 \%)$. Dentre aquelas que seguiam outras religiões, a proporção foi de $9,5 \%$, incluindo o espiritismo e o budismo e 7,7\% citaram não seguir nenhuma religião.

No que diz respeito à ocupação, a maioria $(62,7 \%)$ das puérperas dedicava-se às atividades no próprio lar e 37,3\% exerciam algum tipo de trabalho remunerado.

Em um estudo sobre as condições de vida da população do Estado de São Paulo, constatou-se que a proporção de donas de casa foi maior nos domicílios onde os chefes de família tinham menor escolaridade, fato este que se refletia também nas condições de moradia. Famílias com estas características habitavam, com menor frequência, em domicílios adequados, ou seja, casas ou apartamentos dispondo de rede de água, esgoto e iluminação elétrica ligada à rede pública (César, 2005).

Quanto às características sociodemográficas dos parceiros, constatouse que a maior proporção pertencia à mesma faixa etária que as puérperas, ou seja, de 20 a 29 anos. A escolaridade deles variou entre nenhuma até o ensino superior completo e a maior proporção tinha o ensino fundamental. Estes homens frequentaram a religião católica era maioria (50,9\%), seguida da religião evangélica $(21,3 \%)$, e $18,3 \%$ não possuíam religião.

Semelhanças entre as características sociodemográficas das puérperas e seus parceiros foram constatadas.

Dados do IBGE de 2000 indicam que os brasileiros são majoritariamente cristãos, ou seja, católicos ou evangélicos. Neste censo, a proporção de católicos foi de $73,8 \%$ e a de evangélicos, de $15,45 \%$. No entanto, observou-se que o número de brasileiros que se declarava sem religião cresceu de 1,9\% para 7,3\% nos últimos 20 anos (Antoniazzi, 2003; Azevedo, 2004). 
O catolicismo também tem sido a principal religião (62\%) das mulheres brasileiras e as religiões evangélicas constituem a segunda opção, com 13,1\% (Brasil, 2008,).

No que se referiu às características sociodemográficas e a sua relação com a ocorrência da ITU na gravidez, não foi constatada a existência de relação significativa entre essas variáveis.

Em um estudo realizado na Turquia, foi observada que a maior prevalência de bacteriúria esteve presente entre as mulheres com 8 anos ou menos de estudo. Nessa pesquisa, que também se analisou a variável relativa à renda, foi possível constatar que o baixo poder econômico estava relacionado com a subutilização de serviços de saúde, práticas de higiene inadequadas e condições de moradias precárias que, segundo a avaliação desses pesquisadores, poderia influenciar a alta frequência de bacteriúria (Gunes et al, 2005).

Em relação às características relativas aos tipos de parto atual, assistência pré-natal e paridade, observou-se nesse estudo que a maioria das puérperas teve parto normal (63,7\%) e 32,7\% tiveram parto por via cesárea. A maior proporção de puérperas realizou sete ou mais consultas de pré-natal, ocorridas com maior frequência em serviços públicos. No entanto, $6,8 \%$ das puérperas não frequentaram o serviço pré-natal. Em relação à paridade, a maioria $(60,0 \%)$ das puérperas já possuía filhos.

Nesta pesquisa, a maioria das puérperas $(66,8 \%)$ não apresentou ITU na gravidez, porém 33,2\% relataram a ocorrência dessa patologia e uma proporção (39,5\%) não apresentou sintomas de ITU na gravidez. No entanto, $25,5 \%$ citaram a ocorrência de dor em baixo ventre e 18,5\% mencionaram dois ou mais sintomas associados.

Os dados da literatura indicaram que a frequência da ITU na gravidez variou entre $5 \%$ e $25 \%$ como já referida na introdução. Portanto, a frequência da ITU identificada nesse estudo foi elevada em relação à literatura.

Quanto às relações entre as características da assistência pré-natal e antecedentes obstétricos e a ocorrência de ITU na gravidez, não foi constatada a existência de associação significativa. 
A OMS considerou que as taxas de parto por cesárea acima de 15\% são injustificáveis. Diante das altas taxas de cesárea no Brasil, o Ministério da Saúde instituiu limites para o pagamento de cesáreas pelo Sistema Único de Saúde (SUS) em até 30\%. Apesar disso, o Brasil apresentou, em 2002, uma taxa total de 39,9\% com variações regionais. As taxas médias de cesárea foram menores nos municípios que apresentavam condições socioeconômicas menos favoráveis (World Health Organization, 1985; Brasil, 2002).

Dados da Pesquisa Nacional de Demografia e Saúde de 2006 indicaram taxas de cesárea, nos partos financiados pelo SUS, entre $44 \%$ e 33,6\% nas diferentes regiões brasileiras (Brasil, 2008).

O Ministério da Saúde recomenda a realização de um mínimo de seis consultas durante a gravidez. No Brasil, em 2006, constatou-se que $77 \%$ das gestantes tinham seguido essa recomendação. No caso das usuárias do SUS, a proporção foi de 74\%. No entanto, em razão das diferenças regionais, o Sudeste apresentou uma taxa de $84,7 \%$ e a proporção de gestantes que não realizou nenhuma consulta de pré-natal foi de $0,2 \%$ (Brasil, 2007, Brasil, 2008).

As puérperas deste estudo fizeram mais consultas de pré-natal em comparação com a média nacional, visto que 60,9\% tinham realizado sete ou mais consultas. Por outro lado, a proporção de puérperas deste estudo que não frequentou $(6,8 \%)$ o serviço de assistência pré-natal foi maior que a média nacional. Esse dado requer investigações mais focalizadas para precisar melhor os fatores que interferem na decisão de não aderir às recomendações para realização do pré-natal.

Em relação à presença dos parceiros como acompanhantes nas consultas de pré-natal, constatou-se que 46,4\% não participaram de nenhuma consulta, $33,6 \%$ estiveram presentes em uma a três consultas e $20 \%$ compareceram a quatro ou mais consultas de pré-natal.

Em um estudo realizado em Porto Alegre, constatou-se que 68\% dos pais acompanharam alguma consulta de pré-natal (Piccinini et al, 2004).

De acordo com a Lei Federal $n^{\circ} 11.108$, de 7 de abril de 2005, a mulher tem o direito ao acompanhante de escolha no pré-parto, parto e pós-parto. A 
gestante, que é usuária do SUS, também tem o direito a presença do acompanhante durante as consultas de pré-natal (Brasil, 2006).

A promoção de maior envolvimento masculino na saúde sexual, reprodutiva e da mulher foi uma das recomendações constantes no documento produzido por especialistas participantes da Conferência Internacional de População e Desenvolvimento, na cidade do Cairo em 1994 (Villela, 2004). Na ocasião, foi recomendada a realização de ações voltadas à formulação de políticas públicas e desenvolvimento de projetos com a finalidade de promover a participação dos homens na assistência à saúde da mulher. Desde então, a presença masculina nos cenários de assistência à saúde da mulher apresentou um crescente aumento, mas ainda não constitui uma realidade sedimentada no contexto brasileiro. Acredita-se, portanto, que ações voltadas à promoção da maior participação masculina na assistência à saúde materna devam ser instituídas pelos profissionais.

Quanto à participação da puérperas em grupo de gestantes, observouse que a maior proporção $(84,5 \%)$ não integrou este tipo de atividade. Avalia-se que esta participação seja estimulada e facilitada, tanto às gestantes como aos seus parceiros, pois ela promove o crescimento dos integrantes do grupo. Isto ocorre mediante uma participação ativa nas discussões e reflexões, que se originam durante as interações grupais e outras atividades desenvolvidas (Reberte, Hoga, 2005; Hoga, Reberte, 2007).

No presente estudo, ficou comprovada a inexistência de associações entre as características relativas à moradia, hábitos de higiene, higienização das roupas íntimas, uso de absorventes na gestação e a ocorrência da ITU na gravidez.

A maioria $(79,5 \%)$ das puérperas possuía banheiro na residência, que era provido de chuveiro e pia e 13,6\% referiram dispor de bidê na própria residência. Um estudo americano demonstrou que em $53 \%$ das residências das mulheres havia dois banheiros e apenas $2 \%$ utilizava o bidê para realizar a higiene genital (Czerwinski, 1996). Portanto, observou-se que no presente estudo uma proporção maior de mulheres tinha acesso ao bidê para realizar a higiene genital. 
A maioria das puérperas utilizava o sabão em pó para lavar as roupas íntimas e a maior proporção lavava as roupas íntimas à mão e secava as roupas em local onde havia presença de luz solar. No entanto, para $4,1 \%$ das puérperas o local de secagem das roupas íntimas era o próprio banheiro, sem exposição à luz solar. Este dado indica que os profissionais de saúde devem abordar itens relativos às práticas adequadas de secagem das roupas íntimas, visto que o banheiro, por se tratar de local úmido e sem luz solar, sendo propício ao crescimento de germes.

Em relação à utilização dos absorventes externos, neste estudo, a maioria $(74,1 \%)$ referiu não utilizar durante a gestação. Alguns autores sugeriram que o uso diário desse material aumenta o risco de infecção urinária. Este problema ocorre em razão da transferência dos microorganismos presentes na região perianal, como a E. coli, para o introito vaginal. As bactérias entéricas também foram identificadas com maior freqüência na vagina de mulheres que faziam uso dos absorventes externos e internos (Watt et al, 1981).

Os micro-organismos entéricos estão com frequência presentes na região perineal e nos lábios maiores e ausentes na região do introito vaginal e periuretral. Portanto, não constituem fator de risco para a ocorrência da ITU (Stamey, Sexton,1975; Stapetlon et al, 1995).

Pesquisadores que fizeram revisão sistemática de ensaios clínicos comprovaram que o uso diário de absorventes externos não estava associado à colonização de bactérias causadoras da ITU (Farage et al, 2007). Esta constatação permite sugerir que a decisão sobre o uso dos absorventes externos na gravidez, período em que pode ocorrer um aumento das secreções vaginais, pode ficar a critério das próprias gestantes.

Quanto aos hábitos de higiene após as eliminações vesicais, observouse que a maior proporção $(41,4 \%)$ das puérperas higienizavam, limpando com papel higiênico com movimentos de frente para trás e $(38,6 \%)$ limpava com papel higiênico ou lenço umedecido sem atentar para o sentido dos movimentos de higiene após a micção. Salienta-se, entretanto, que 15,4\% das puérperas referiram a prática de higiene, após as micções no sentido 
póstero-anterior e 1,4\% não faziam nenhum tipo de higiene após as micções.

Não houve associação entre as características relativas aos hábitos de higiene das puérperas e de seus parceiros, após eliminações vesicointestinais e a ocorrência de ITU autorreferida na gravidez.

Pesquisa realizada com uma amostra de mulheres inglesas demonstrou que $48 \%$ delas tinham o hábito de fazer higiene da genitália, após as micções no sentido ântero-posterior e 44\% faziam-se no sentido inverso. Nesse estudo, concluiu-se que o hábito de limpar os órgãos genitais externos no sentido póstero-anterior tinha associação com a ocorrência da ITU na gestação (Persad et al, 2006).

Os resultados antagônicos, que estão na dependência das variáveis estudadas, indicam que mais estudos enfocando essa questão precisam ser desenvolvidos. Há necessidade de obter maior clareza em relação a esse assunto, pois possui implicações diretamente relacionadas à prática educativa das gestantes.

A maioria $(50,5 \%)$ das mulheres fazia higiene, após as evacuações limpando com papel higiênico ou lenço umedecido com movimentos de frente para trás. É necessário salientar, entretanto, que 7,7\% das puérperas realizavam higiene no sentido contrário, ou seja, de trás para frente e 0,9\% não fazia nenhum tipo de higiene. Este costume favorece a colonização da vagina e da região uretral por micro-organismos próprios da flora enteral. Embora esta pesquisa tenha demonstrado a inexistência de relação significativa entre as práticas de higiene após eliminações vesicais ou intestinais e a ocorrência da ITU na gravidez, os pesquisadores que estudam essa temática foram unânimes quanto à recomendação de realizar a higiene após eliminações vesicointestinais no sentido ântero-posterior (Halbe, 1993, Almeida, 2000, Sunders, 2002).

A prática de higiene após as eliminações vesicais e intestinais já foi estudada. Constatou-se que a higiene no sentido de frente para trás foi adotada por $52 \%$ das mulheres e $19 \%$ não realizam a prática (Czerwinski, 1996). 
Os estudiosos do assunto recomendam que a higiene após as evacuações deva ser feita levando a mão por trás do corpo e limpando a região anal, em um movimento unidirecional, partindo do períneo e indo ao sentido do ânus e cóccix. O movimento contrário não deve ser realizado porque, caso seja feito, pode determinar a contaminação da vagina e uretra pela flora entérica. A contaminação do vestíbulo vaginal e da uretra por bactérias entéricas e sua colonização constituem fatores determinantes das infecções no trato urinário e das vulvovaginites (Halbe, 1993; Almeida, 2000; Sunders, 2002).

$\mathrm{Na}$ relação entre ITU e práticas de higiene genital dos parceiros, observou-se que a maioria não realizava nenhum tipo de higiene após a micção. Cerca de um terço dos parceiros limpava com papel higiênico com movimentos de frente para trás, após evacuar e parecida proporção de parceiros limpava com papel higiênico ou lenço umedecido sem atentar para o sentido dos movimentos de higiene após evacuação.

Os profissionais devem estar atentos a esta questão e identificar os hábitos de higiene adotados pelas gestantes e seus parceiros. Caso seja diagnosticada a necessidade, será preciso fazer a intervenção educativa requerida no sentido de preservar as boas condições higiênicas dos órgãos genitais de ambos.

A má higiene masculina que, além de compreender o não lavar adequadamente o pênis antes do coito, pode se relacionar a ter relações sexuais na vigência de uretrites, condilomas e herpes. Essas patologias podem acarretar sérias consequências, imediatas ou tardias, para a mulher. As imediatas referem-se à contaminação por agentes causadores de doenças sexualmente transmissíveis e, as tardias, à possibilidade de evoluir para o câncer de colo uterino (Almeida, 2000).

Na relação entre ITU e os hábitos sexuais na gestação, observou-se que a maioria das puérperas teve apenas um parceiro sexual na gravidez e manteve relação do tipo vaginal, com frequência de atividade sexual semanal. Observou-se, entretanto, a existência de 3,6\% de puérperas que mencionaram a prática do coito anal. 
Nos resultados do presente estudo, não foram constatadas associações entre as características dos hábitos sexuais e a ocorrência da ITU na gravidez.

A atividade sexual é considerada por alguns autores como um dos fatores predisponentes da ocorrência da ITU. Estima-se que este problema ocorra em razão do efeito mecânico, que acarreta a introdução de elementos patógenos no terço distal da uretra e na bexiga. Mulheres com intensa atividade sexual apresentam $40 \%$ a mais risco de desenvolver infecção urinária quando comparadas àquelas que não têm atividade sexual. Estimou-se que os episódios de infecção podem ocorrer após 12 horas do relacionamento sexual (Sheikh et al, 2000). As conclusões desse estudo foram reiteradas por pesquisadores brasileiros que concluíram que as mulheres com intensa atividade sexual apresentaram risco 40\% maior de desenvolver infecção urinária (Girão, Bacarat, Lima, 2002).

Dados a respeito da frequência de sexo anal durante a gravidez permanecem desconhecidos. Esta prática é permeada por controvérsias, mas há a recomendação para que o parceiro utilize um lubrificante à base de água para diminuir seus desconfortos. Também há contraindicação desta prática pelas mulheres que apresentam hemorroidas nesta região (Polomeno, 2000).

Os dados da literatura demonstraram que na gravidez ocorre um declínio da frequência das atividades sexuais, especialmente, no terceiro trimestre. Estima-se que esta redução deva-se aos desconfortos provocados pelos posicionamentos requeridos na prática das relações sexuais, que podem provocar a congestão pélvica e o encaixe do polo cefálico na pelve materna (Polomeno, 2000).

Nos casos em que a mulher apresenta ruptura prematura de membranas (RPM) ou risco de trabalho de parto prematuro (TPP) relacionado à ocorrência da ITU, recomenda-se a interrupção das relações sexuais, pois sua prática aumenta o risco de infecções provocadas pela penetração do pênis e do surgimento de contrações uterinas provocadas pelo orgasmo (Polomeno, 2000). 
Estudo americano relacionando a ocorrência da ITU e o comportamento sexual na gravidez demonstrou que $28 \%$ tinham o hábito de manter relações sexuais anais na gravidez. Quanto ao número de parceiros durante a gestação, $73 \%$ referiram ter tido parceiro único e $27 \%$ dois ou mais parceiros. A atividade sexual foi considerada como o fator de risco mais importante para ocorrência da ITU recorrente em mulheres em idade reprodutiva, pois promove a colonização do introito vaginal e uretral pela $E$. coli, sobretudo, em mulheres que possuem suscetibilidade (Dwyer, 2001).

Acredita-se que as doenças sexualmente transmissíveis não sejam agentes causadores da ITU. Entretanto, a prática sexual é um dos meios mais comuns de transporte mecânico de bactérias da pele do redor do ânus para a vagina e a uretra. A prática sexual também pode traumatizar a uretra, podendo acarretar o aparecimento da ITU, o que pode favorecer o transporte de bactérias para a bexiga (American College of Nurse-Midwives, 2005).

O tipo de hábito sexual durante a gravidez deve ser identificado pelos profissionais, pois este dado é preciso para reconhecer a possível necessidade de orientações a esse respeito. Sobretudo a realização do coito vaginal, após o coito anal deve ser identificada, pois esta prática não é recomendada pelo fato de determinar a contaminação da flora vaginal pela entérica. Neste aspecto, avalia-se que os profissionais em seu trabalho educativo devem evitar avaliações de natureza moral e, portanto, as preferências dos clientes devem ser respeitadas. Quando o coito vaginal seguido do anal for do desejo do casal, é necessário que os profissionais os alertem quanto ao fato desta prática ser intercalada com uma higiene adequada do pênis (Almeida, 2000).

A maioria das puérperas deste estudo tomava banho de chuveiro antes e depois do coito. Quanto aos parceiros, a maior proporção $(45,4 \%)$ tomava banho de chuveiro antes da relação sexual, seguido por aqueles (26,3\%) que lavavam o pênis com água e sabonete. A maior proporção $(58,7 \%)$ tomava banho de chuveiro depois do ato sexual e $27,7 \%$ lavavam o pênis com água e sabonete.

Chama a atenção o fato da maioria (84,5\%) das puérperas não ter mencionado o recebimento de orientações a respeito das práticas de higiene 
genital durante a gravidez na assistência pré-natal. Dentre as 34 puérperas que receberam informações na gravidez, 55,9\% citaram que o profissional que realizou a orientação foi o médico. A maioria dos parceiros também não recebeu informações sobre a ITU e os hábitos de higiene genital.

A constatação da existência de práticas inadequadas de higiene genital após eliminações vesicais e intestinais e nas relações sexuais reforça a necessidade dos profissionais atentarem para este fato e desempenhar adequadamente seu papel educativo na assistência pré-natal.

Isto está previsto no Programa de Humanização do Pré-Natal e Nascimento (PHPN) (Brasil, 2007). Neste Programa, estão estabelecidos os princípios que devem dirigir a assistência a ser prestada às gestantes no decurso da assistência pré-natal. Nele, está salientada a necessidade dos profissionais cumprirem adequadamente seus papéis, pois isto é essencial para que as gestantes recebam uma assistência humanizada e com boa qualidade.

No manual intitulado "Parto, Aborto e Puerpério - uma assistência humanizada à mulher", consta a premissa do oferecimento de ações educativas visando ao preparo para o nascimento e o parto. Nele foi salientado que tais práticas sejam realizadas com o intuito de atender aos desejos, valores e ao conjunto de demandas apresentadas pelas mulheres, de modo a respeitá-la como pessoa de direitos (Brasil, 2001). Acredita-se também na necessidade de respaldo científico das orientações fornecidas.

Nesse sentido, diante das constatações obtidas no presente estudo, avalia-se a necessidade de atualizar os protocolos de orientação de enfermagem para a prevenção da ITU na gestação. Em um deles (Barros, Paula, Rodrigues, 1997), consta que a gestante deve prevenir a ocorrência da ITU mediante, entre outros aspectos, a execução da higiene da região vulvoperineal de maneira correta. Acredita-se que este tipo de orientação seja fornecido. Entretanto, é preciso salientar com as gestantes que esta medida não é uma garantia para a não ocorrência da ITU na gravidez, como foi comprovada nesta pesquisa. 


\section{CONCLUSÕES}

皮 


\section{CONCLUSÕES}

Esta pesquisa apresentou as seguintes conclusões:

- Quanto às características sociodemográficas das puérperas, não houve associação significativa entre os itens idade $(p=0,340)$, escolaridade $(p=0,735)$, religião $(p=0,322)$, trabalho remunerado $(p=0,122)$ e a ocorrência da ITU na gravidez.

- Quanto às características sociodemográficas dos parceiros, não houve associação significativa entre os itens idade $(p=0,605)$, escolaridade $(p=0,123)$, religião $(p=0,322)$, participação nas consultas do pré-natal $(p=0,074)$ e a ocorrência da ITU na gravidez.

- Quanto às características do tipo de parto atual, pré-natal e paridade não houve associação significativa entre os itens tipo de parto $(p=$ $0,574)$, realização de pré-natal $(p=0,558)$, local de realização do prénatal $(p=0,222)$, a participação em grupos de orientação $(p=0,581)$, a existência de filhos $(p=0143)$, o tipo de parto anterior $(p=0,135)$ e a ocorrência da ITU na gravidez.

- Quanto às características dos banheiros utilizados pelas puérperas, não houve associação significativa entre os itens existência de banheiro na residência $(p=0,339)$, existência de banheiro exclusivo para o casal $(p=0,235)$, as características do banheiro no local de trabalho $(p=0,087)$ e a ocorrência da ITU na gravidez.

- Quanto às características de higienização das roupas íntimas, não houve associação significativa entre os itens produto utilizado na lavagem $(p=0,533)$, a forma de lavagem $(p=0,613)$, a forma de secagem $(p=0,719)$ e a ocorrência da ITU na gravidez.

- Quanto aos hábitos de uso dos absorventes higiênicos externos e internos, não houve associação significativa entre os itens uso de absorvente externo $(p=0,161)$ e o absorvente interno $(p=0,825)$ e a ocorrência da ITU na gravidez.

- Quanto às características da higiene genital das puérperas, não houve associação significativa entre os itens hábitos após as miç̧ões ( $p=$ 
0,829) e após as evacuações $(p=0,642)$ e a ocorrência da ITU na gravidez.

- Quanto às características de higiene genital dos parceiros, não houve associação significativa entre os itens hábito após as micções ( $p=$ 0,378) e após as evacuações $(p=0,658)$ e ocorrência da ITU na gravidez.

- Quanto às características dos hábitos sexuais, não houve associação significativa entre os itens número de parceiros $(p=0,326)$, tipo de relação sexual $(p=0,182)$, frequência das relações sexuais $(p=0,537)$ e ocorrência da ITU na gravidez.

- Quanto às características dos hábitos de higiene das puérperas nas relações sexuais, não houve associação significativa entre os itens hábitos antes $(p=0,741)$ e após o coito $(p=0,277)$ e a ocorrência da ITU na gravidez.

- Quanto às características dos hábitos de higiene dos parceiros nas relações sexuais, não houve associação significativa entre os itens hábitos antes $(p=0,964)$ e após o coito $(p=0,074)$ e a ocorrência da ITU na gravidez.

- Quanto às orientações sobre higiene genital, não houve associação significativa entre os itens existência de orientação às gestantes ( $p=$ $0,0553)$ e aos parceiros $(p=0,162)$ e a ocorrência da ITU na gravidez. 
CONSIDERAÇÕES FINAIS 


\section{CONSIDERAÇÕES FINAIS}

Neste estudo foram constatados alguns fatos que merecem atenção especial dos profissionais de saúde, visto que desempenham um papel fundamental na educação e promoção da saúde na gravidez.

Um deles diz respeito à existência de puérperas que não adotavam práticas de higiene após as evacuações e homens que não realizavam nenhum tipo de higiene após as micções.

Importa considerar que as mulheres tomam para si a incumbência de educar os filhos e estabelecer diálogos a respeito dos comportamentos apropriados, inclusive, os relacionados à saúde (Santin, 1999). Avalia-se que este dado seja considerado e, portanto, o enfoque das orientações relacionadas à higiene genital pode ser direcionado primordialmente às mães, pois elas poderão constituir fontes de informação aos demais integrantes da família, sobretudo, os filhos.

Tornou-se evidente que a maioria das gestantes procura assistência nos serviços de pré-natal. Entretanto, muitas delas ficaram sem obter orientações consideradas básicas, como as relativas aos cuidados de higiene necessários durante a gravidez.

Embora as recomendações a este respeito estejam reiteradamente presentes nos programas direcionados à assistência pré-natal, é necessário reforçar a importância das ações educativas visando à educação e promoção da saúde na gravidez.

A associação entre as práticas de higiene genital e a ocorrência da ITU na gravidez não foi constatada nesta pesquisa. $O$ fato não diminui a importância das atividades educativas abrangendo esta temática na assistência pré-natal. Os profissionais de saúde devem aprimorar cada vez mais suas habilidades para identificar problemas desse âmbito e, com base nos diagnósticos feitos, planejar e desempenhar as atividades necessárias, mediante um processo comunicativo efetivo.

Ao desenvolver atividades educativas, dentre elas, as orientações a respeito da realização da higiene genital adequada na gravidez, é 
necessário salientar sua importância, mas não é possível garantir que este procedimento reduza chances de ocorrência da ITU na gravidez, como evidenciado nesta pesquisa. No cotidiano assistencial, foi possível perceber que esta associação é mencionada quando os profissionais fornecem às gestantes. Por se tratar de associação não comprovada estatisticamente, não há como continuar mencionando este tipo de associação nas orientações a respeito dos cuidados com a higiene genital fornecidas às gestantes.

Como já salientado no início deste estudo, todos os cuidados e orientações devem ser feitos com base em comprovações científicas e pautadas nas melhores evidências. Além destas ações terem sua eficácia comprovada, é necessário conhecer e considerar as questões contextuais, dentre elas, as dimensões culturais e socioeconômicas dos usuários dos serviços de saúde, assim como suas preferências (Pearson et al, 2005).

A existência de puérperas que não adotavam práticas consideradas básicas, dentre elas, a higiene após as evacuações e entre o coito anal e vaginal, demonstrou que os profissionais devem identificar, de forma sistemática, problemas dessa natureza, independentemente da condição social e de moradia dos usuários dos serviços de saúde. Como já foi salientado, a atuação do enfermeiro nos programas de pré-natal implica preparo clínico para identificar problemas reais e potenciais da gestante, família e comunidade, com vistas ao manejo adequado das diversas situações práticas (Pereira, Bachion, 2005). 
LIMITAÇÕES DA PESQUISA E RECOMENDAÇÕES PARA NOVOS ESTUDOS 


\section{LIMITAÇÕES DA PESQUISA E RECOMENDAÇÕES PARA NOVOS ESTUDOS}

Ao concluírem um estudo, todos os pesquisadores devem analisar criticamente a própria investigação realizada, pois por meio dela é possível identificar suas limitações e sugerir novas pesquisas.

Nesse sentido, há de se admitir que esta pesquisa restrita à abordagem quantitativa não permitiu acessar os aspectos subjetivos do tema abordado. Dentre eles, destacam-se aspectos como as razões da não realização do pré-natal, a ausência dos parceiros nas consultas, a não adesão aos grupos de gestantes e o conteúdo e formas de abordagem das orientações no pré-natal.

Em relação ao acesso aos exames urina I e/ou carteira de pré-natal para averiguação de ocorrência de ITU na gravidez, verificou-se que a maioria das puérperas não levou a carteira da gestante que contém as informações relativas aos exames de urina I ou anotações pertinentes à Instituição onde receberam assistência pré-natal. $O$ fato impossibilitou a verificação dos resultados e, portanto, este dado relativo à ocorrência da ITU na gravidez foi apenas questionado com as puérperas. Estima-se que este problema não tenha interferido sobre os resultados desta pesquisa. Por outro lado, é possível reafirmar a necessidade de enfatizar a importância do porte da carteira da gestante no momento de buscar assistência ao parto.

Diante da constatação da inexistência de associações significativas entre as variáveis estudadas nesta pesquisa e a ocorrência da ITU na gravidez, há que se atentar para o fato de fatores não abordados poderem estar interferindo no aparecimento desta patologia na gravidez. Isto demanda a necessidade de considerar a integralidade das gestantes como seres sociais. Fatores como hábitos alimentares, estresse, qualidade de vida e outros que extrapolam a dimensão física e sua associação com a ocorrência da ITU na gravidez merecem ser investigadas. 


\section{REFERÊNCIAS}




\section{REFERÊNCIAS}

Almeida AB. Higiene feminina. In: Halbe, HV. Tratado de ginecologia. $2^{\underline{a}}$ ed. São Paulo: Roca; 2000.

Andriole VT. Urinary tract infections in the 90s: pathogenesis and management. Infectin. 1992;20(4)251-6.

American College of Nurse-Midwives. Share with women. Urinary tract infections. J Midwifery Womens Health. 2005;50(6):551-2.

Antoniazzi A. As religiões no Brasil segundo o censo de 2000. Rev Estud Religião [periódico na internet]. 2003 [citado 2009 mar. 11];3(2):75-80. Disponível em: http://www.pucsp.br/rever/rv2_2003/p_antoni.pdf.

Aquino TA, Guimarães MJB, Sarinho SW, Ferreira LOC. Fatores de risco para mortalidade perinatal no Recife, Pernambuco, Brasil, 2003. Cad Saúde Pública. 2007;23(12):2853-61.

Azevedo D. A Igreja Católica e seu papel político no Brasil. Estud Av. 2004;18(52):109-20.

Barros SMO, Marin HF, Abrão ACFV. Enfermagem obstétrica e ginecológica: guia para a prática assistencial. São Paulo: Roca; 2002. p. 105-41.

Barros SMO. Análise da qualidade da assistência pré-natal prestada pela enfermeira-obstetra no Amparo Maternal [dissertação]. São Paulo: Escola Paulista de Medicina; 1990.

Barros SMO, Paula CADP, Rodrigues SSMWR. Infecção urinária entre gestantes: intervenções de enfermagem para sua prevenção e tratamento. Acta Paul Enferm. 1997;10(1):93-9.

Batista CS. Infecção do trato urinário na gestação: conduta. Femina. 2002;30(8):553-5.

Belfort P. Assistência pré-natal. In: Rezende J. Obstetrícia. 8ª ed. Rio de Janeiro: Guanabara Koogan; 1998. p. 260-76.

Brasil. Ministério da Saúde. Secretaria de Vigilância Sanitária. Portaria no 97, de 04 de outubro de 1995. Coloca a substância amineptina e os medicamentos à base dela na lista DIMED 27/86 [legislação na internet].

Diário Oficial da União, Brasília, 09 out. 1995 [citado 2009 mar. 11].

Disponível em:

http://elegis.anvisa.gov.br/leisref/public/showAct.php?id=698\&word=.

Brasil. Ministério da Saúde. Conselho Nacional de Saúde. Resolução n. 196, de 10 de outubro de 1996. Diretrizes e normas regulamentadoras de pesquisa em seres humanos. Mundo Saúde. 1996;21(1):52-61.

Brasil. Ministério da Saúde. Secretaria de Políticas de Saúde (SPS). Assistência pré-natal: manual técnico. 3ª ed. Brasília; 2000. 
Brasil. Ministério da Saúde. Secretaria de Políticas de Saúde (SPS). Parto, aborto e puerpério: assistência humanizada à mulher. Manual técnico.

Brasília; 2001.

Brasil. Ministério da Saúde. Departamento de Informática do SUS. Sistema de informação de nascidos vivos, 2002 [texto na internet]. Brasília ; c2008 [citado 2009 mar. 11]. Disponível em: http://www.datasus.gov.br/sinasc.htm

Brasil. Ministério da Saúde. Secretaria de Ciência, Tecnologia e Insumos Estratégicos. Departamento de Ciência e Tecnologia. Agenda nacional de prioridades em pesquisa em saúde. Brasília; 2004.

Brasil. Ministério da Saúde. Lei n. 11.108, de 07 de abril de 2005. Carta dos direitos dos usuários dos serviços de saúde. Brasília; 2006.

Brasil. Ministério da Saúde. Programa de Humanização do Pré-Natal e Nascimento. Informações para gestores e técnicos: manual técnico. Brasília; 2007.

Brasil. Ministério da Saúde. PNDS 2006. Pesquisa Nacional de Demografia e Saúde. Saúde da criança e da mulher [texto na internet]. Brasília; 2008 [citado 2009 mar. 11]. Disponível em:

http://bvsms.saude.gov.br/bvs/pnds/index.php.

César CLG. Condições de Vida. In: César CLG, Carandina L, Alves MCGP, Barros MMA, Goldbaum M. Saúde e condição de vida em São Paulo: inquérito multicêntrico de saúde no Estado de São Paulo. São Paulo: Faculdade de Saúde Pública, Universidade de São Paulo; 2005. p. 65-78.

Conde-Agudelo A, Villar J, Lindheimer M. Mathernal infection and risk of preclampsia systematic review and metaanalysis. Am J Obstet Ginecol. 2008;198(1):7-22.

Czerwinski BS. Adult feminine hygiene pratices. Applied Nurs Res. 1996;9(3):123-9.

Delcroix M, Zone V, Cheront C, Adam MH, Duquesne G, Noel AM. $L$ 'infection urinaire de la femme enceinte. Rev Fr Gynecol Obstet . 1994;89:277-84.

Delzell JE, Lefreve ML. Urinary tract infections during pregnancy. Am Fam Physician. 2000;61:713-21.

Duarte G, Marcolin AC, Gonçalves CV, Quintana SM, Berezowski AT, Nogueira AA, et al. Infecção urinária na gravidez: análise dos métodos para diagnóstico e do tratamento. Rev Bras Ginecol Obstet. 2002;24(7):471-7.

Duarte G, Marcolin AC, Quintana SM, Cavalli RC. Infecção urinária na gravidez. Rev Bras Ginecol Obstet. 2008;30(2):93-100.

Duarte G. Infecções genito-urinária na gravidez. In: Alves Filho N, Correa MD, Alves Jr, Correa Jr MD, editores. Perinatologia básica. 3ª ed. Rio de Janeiro: Guanabara Koogan; 2006. p. 129-41. 
Dwyer JM. High-risk sexual behaviour and genital infections during pregnancy. Int Nurs Rev. 2001,48(4):233-40.

Farage M, Bramante M, Otaka Y, Sobel J. Do pant liners promote vulvovaginal candidiasis or urinary tract infections? A review of the scientific evidence. Eur J Obstet Gynecol Reprod Biol. 2007;132(1):8-19.

Ferreria FE, Olaya SXO, Zúniga $\mathrm{P}$, Angulo M. Infeccion urinaria durante el embarazo, perfil de resistência bacteriana al tratamiento em el hospital general de Neiva, Colombia. Rev Colomb Obstet Ginecol. 2005;56(3):23943.

Gilstrap 3rd LC, Ramin SM. Urinary tract infections during pregnancy. Obstet Gynecol Clin North Am. 2001;28(3):581-91.

Girão MJBC, Baracat EC, Lima GR. Urinary tract infections: immunological aspects. Int Urogynecol J Pelvic Floor Dysfunct. 2002;13(3):195-7. Review.

Gorgas, DL. Infections related to pregnancy. Emerg Med Clin North Am. 2008;26(2):345-66, viii. Review.

Goulart AP, Valle CF, Dal-Pizzo F, Cancelier ACL. Fatores de risco para o desenvolvimento de sepse neonatal precoce em hospital da rede pública do Brasil. Rev Bras Ter Intensiva. 2006;18(2):148-53.

Gunes G, Gunes A, Tekiner S, Karaoglu L, Kaya M, Pehlivan E. Bacteriuria and socioeconomic associations among pregnant women in Malatya, Turkey. Public Health. 2005;119(11):1339-41.

Halbe HV. Tratado de ginecologia. $2^{a}$ ed. São Paulo: Roca; 1993. p. 76-81.

Heilberg IP, Schor N. Abordagem diagnóstica e terapêutica na infecção do trato urinário: ITU. Rev Assoc Med Bras. 2003, 49(1):109-16.

Kisztajn S, Rossbach AC, do Carmo MSN, Sugahara TL. Assistência prénatal, baixo peso e prematuridade no Estado de São Paulo, 2000. Rev Saúde Pública. 2003;37(3):303-10.

Krcmery S, Hromec J, Demeova D. Treatment of lower urinary tract infection in pregnancy. Int J Antimicrob Agents. 2001;17(4):279-82.

Hoga LAK, Reberte LMR. Pesquisa-ação como estratégia para desenvolver grupo de gestantes: a percepção dos participantes. Rev Esc Enferm USP. 2007;41(4):559-66.

Lajos GJ, Junior RP, Nomura ML, Amaral E, Pereira BG, Milanez H, Parpinelli MA. Colonização bacteriana do canal cervical em gestantes com trabalho de parto prematuro ou ruptura prematura de membranas. Rev Bras Ginecol Obstet. 2008;30(8):393-9.

Lee M, Bozzo P, Einarson A, Koren G. Urinary tract infections in pregnancy. Can Family Physician. 2008;54:853-4. 
Macejko AM, Schaeffer AJ. Asymptomatic bacteriúria and symptomatic urinary tract infections during pregnancy. Urol Clin North Am. 2007;34(1):3542.

MacLean AB. Urinary tract infection in pregnancy. Int J Antimicrob Agents. 2001;17(4):273-6; discussion 276-7. Review.

Marinelli CM, Rodrigues AO, Aragão AJ, Predeus AAV, Barbosa CP, Wroclawski. Infecção do trato urinário na gestação. Femina. 2002;30(5):299303.

McKenzie H, Donnet ML, Howie PW, Patel NB, Benvie DT. Risk of preterm delivery in pregnant women with group $B$ streptococcal urinary infections or urinary infections or urinary antibodies to group B streptococcal and E. Coli antigens. Br J Obstet Gynaecol. 1994;101(2):107-13.

Millar LK, Cox SM. Urinary tract infections complicating pregnancy. Infect Dis Clin North Am. 1997;11(1):13-26. Review.

Moreira MA. O valor da higiene íntima. Femina. 1986;14(7):880-2.

Neme B. Obstetrícia básica. $2^{\underline{a}}$ ed. São Paulo: Sarvier; 2000. p. 37-50.

Pastore LM, Savitz DA, Thorp JM Jr, Koch GG, Hertz-Picciotto I, Irwin DE. Predictors of symptomatic urinary tract infection after 20 weeks' gestation. J Perinatol. 1999;19(7):488-93

Palacios YVF, Gómez CFE, Canese J, Canese JO, Franco YEP. Alta frecuencia de infeccion urinaria en el embarazo-un estudio de 100 pacientes. Rev Med Actual. 2001;1(2):15-20.

Paula LG. Krahe C, Carvalho RL. Infecção urinária e gestação. Femina. 2005;33(3):209-13.

Pearson A, Wiechula R, Court A, Lockwood C. The JBI Model of evidencebased healthcare. Int JEB Healthcare. 2005;3(8):207-15.

Pereira SVM, Bachion MM. Diagnósticos de enfermagem identificados em gestantes durante o pré-natal. Rev Bras Enferm. 2005;58(6):659-64.

Persad S, Watermeyer S, Griffiths, Cherian B, Evans J. Association between urinary tract infection and postmicturition wipping habit. Acta Obst Gynecol. 2006;85:1395-6.

Piccinini CA, Silva MR, Gonçalves TR, Lopes RS. O envolvimento paterno com a gestação. Psicol Reflex Crít. 2004;17(3):303-14.

Polomeno V. Sex and pregnancy: a perinatal educator's guide. J Perinatal Educ. 2000;9(4):15-27.

Quiroga-Feuchter G, Robles-Torres RE, Ruelas-Moran A, Gómez-Alcalá AV. Bacteriúria asintomática em mujeres embarazadas. Rev Med Inst Mex Seguro Soc. 2007;45(2):169-72. 
Reberte LM. Celebrando a vida: construção de uma cartilha educativa para gestantes [dissertação]. São Paulo: Escola de Enfermagem, Universidade de São Paulo; 2008.

Reberte LM, Hoga LAK. O desenvolvimento de um grupo de gestantes com a utilização da abordagem corporal. Texto \& Cont Enferm. 2005;14(2):18692.

Santin MA. Religião e práticas anticoncepcionais - relatório de pesquisa. Belém: Universidade da Amazônia; 1999.

Schaeffer AJ. Recurrent urinary tract infection in female patients. Urology. 1998;3232:12-7.

Sheikh MA, Khan MS, Khatoon A, Arain GM. Incidence of urinary tract infection during pregnancy. East Mediterr Health J. 2000;6(2-3):265-71.

Schieve LA, Handler A, Hershow R, Persky, Davis F. Urinary tract infection during pregnacy: its association with maternal morbidity and perinatal outcome. Am J Public Health. 1994;84(3):405-10.

Sunders RB. Cuidado de enfermagem durante a gestação. In: Lowdermilk DL, Perry SE, Boback IM. O cuidado em enfermagem materna. 5ª ed. Porto Alegre: Artmed; 2002. p. 219-24.

Stamey TA, Sexton CC. The role of vaginal colonization with enteriaceae in recurrent urinary infections. J Urol. 1975;113(2):214-7.

Stapleton A, Hooton TM, Fennell C, Roberts PL, Stamm WE. Effect of secretor status on vaginal and rectal colonization with fimbriates Escherichia coli in women with and without recurrent urinary tract infection. J Infect Dis. 1995;171(3):717-20

Urbanetz AA, Varela AL. Infecção urinária e gravidez. Femina. 1999;22(12):594-604.

Vazquez JC, Villar J. Treatments for symptomatic urinary tract infections during pregnancy. Cochrane Database Syst Rev. 2008;(4).

Villela W. O monitoramento da Plataforma de Ação da Conferência Internacional sobre População e Desenvolvimento no Brasil. Jornal da Rede Feminista de Saúde [periódico na internet]. 2004 [citado 2008 jun. 02];26(12). Disponível em:

http://www.redesaude.org.br/Homepage/JornaldaRede/JR26/Jornal da Rede.26.pdf

Watt B, Goldacre MJ, Loudon N, Annat DJ, Harris RI, Vessey MP. Prevalence of bacteria in the vagina of normal young women. $\mathrm{Br} \mathrm{J}$ Obstet Gynaecol. 1981;88(6):588-95

World Health Organization (WHO). Appropriate technology for birth. Lancet. 1985;2:436-7. 


\section{APÊNDICES}




\section{APÊNDICES APÊNDICE 1 \\ PARECER DO COMITÊ DE ÉTICA EM PESQUISA DA EEUSP}

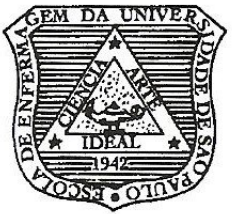

UNIVERSIDADE DE SÃO PAULO

ESCOLA DE ENFERMAGEM

Av. Dr. Enéas de Carvalho Aguiar, 419 - CEP 05403-000

道 Fone: 3061-7548 - Fax: 3061-7548

C.P. 41633 - CEP 05422-970 - e-mail: edipesq@usp.br

São Paulo, 15 de abril de 2008.

II. ${ }^{\mathrm{ma}} \mathrm{Sr}^{\mathrm{a}}$

Mariana Turani

Ref.: Processo ${ }^{0} 720 / 2008 /$ CEP-EEUSP

Prezada Senhora:

Em atenção à solicitação referente à análise do projeto "Hábitos de higiene genital e infecção urinária na gestação", informamos que o mesmo foi considerado aprovado pelo Comitê de Ética em Pesquisa da Escola de Enfermagem da Universidade de São Paulo (CEP/EEUSP).

Analisado sob o aspecto ético-legal, atende às exigências da Resolução nº 196/96 do Conselho Nacional de Saúde.

Esclarecemos que após o término da pesquisa, os resultados obtidos deverão ser encaminhados ao CEP/EEUSP, para serem anexados ao processo.

Atenciosamente,

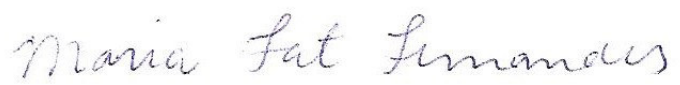

Prof. ${ }^{a}$ Dr. ${ }^{a}$ Maria de Fátima Prado Fernandes Coordenadora do Comitê de Ética em Pesquisa da Escola de Enfermagem da Universidade de São Paulo 


\section{APÊNDICE 2 \\ TERMO DE CONSENTIMENTO LIVRE E ESCLARECIDO \\ (Decreto 93.933 de 14 /01/87; Resolução CNS 196/96.) \\ Prezado Senhora,}

Meu nome é Mariana Turiani, aluna do Mestrado da Escola de Enfermagem da USP e estou fazendo a pesquisa "HÁBITOS DE HIGIENE GENITAL E INFECÇÃO NO TRATO URINÁRIO AUTORREFRIDA NA GRAVIDEZ". Para tanto, irei fazer perguntas através de um questionário para as mulheres que deram à luz neste hospital, com a finalidade de obter uma compreensão ampla e profunda a esse respeito, que é importante para os profissionais que prestam assistência nesta área.

Este documento contém duas vias, sendo que uma ficará em seu poder e a outra comigo, garantindo as condições citadas abaixo.

Agradecendo sua colaboração, coloco-me à disposição para os esclarecimentos que se fizerem necessários pelo telefone: 2978-3450.

Eu RG n.

abaixo-assinado, tendo recebido as informações acima, aceito participar voluntariamente da pesquisa, ciente de meus direitos relacionados a seguir:

- A liberdade de deixar de participar no estudo, sem que isso me traga algum prejuízo;

- A segurança de saber que tudo o que eu disser, será mantido em segredo;

- Saber que o que eu falar será transformado em trabalho científico e apresentado em congressos e revistas da área da saúde, em nenhum momento meu nome será mencionado.

São Paulo, de de 2008.

Assinatura da colaboradora

$$
\begin{gathered}
\text { Mariana Turiani } \\
\text { Enfermeira Obstetra, } \\
\text { aluna do Mestrado da Escola } \\
\text { de Enfermagem - USP. }
\end{gathered}
$$

Comitê de Ética em Pesquisa da Escola de Enfermagem da Universidade de São Paulo.Telefone:(11)3061-7548. 


\section{APÊNDICE 3 \\ INSTRUMENTO DE COLETA DE DADOS}

№ do Formulário:
1. Data do parto:
2. Tipo de parto deste filho que nasceu:
( ) parto normal com episiotomia ( ) parto normal sem episiotomia
( ) parto cesárea
( ) parto fórcipe

3. Fez consultas de pré-natal nesta gravidez?
( ) não
( ) $\operatorname{sim}$

3.1 Quantas consultas de pré-natal fez? consultas
( ) no serviço público
( ) programa saúde da família ( ) posto de saúde
( ) no médico do convênio
( ) com médico particular

4. Você participou de algum grupo de orientação durante a gravidez?
( ) não
( ) $\operatorname{sim}$
Caso sim, onde?
Que tipo de grupo?
Qual profissional?

5. O pai desta criança acompanhou você nas consultas do pré-natal?

( ) nunca ( ) uma vez ( ) duas vezes ( ) três vezes ( ) todas as vezes

6. A sua idade em anos:

7. A idade do pai desta criança em anos:
8. A sua escolaridade:
( ) não sabe ler/escrever
( ) ensino fundamental
( ) ensino médio (1ำ ao $3^{\circ}$ colegial)
( ) sabe ler/escrever, porém não freqüentou escola
( ) ensino superior
Qual profissão?
( ) $5^{\underline{a}}$ à $8^{\underline{a}}$ série

9. Escolaridade do pai desta criança:
( ) não sabe ler/escrever
( ) sabe ler/escrever, porém não freqüentou escola
( ) ensino fundamental
( ) $1^{\text {a }}$ à $4^{\text {a }}$ série
( ) ensino médio ( $1^{\circ}$ ao $3^{\circ}$ colegial)
( ) ensino superior.
Qual profissão?

\section{A sua religião é:}
( ) católica
( ) budista
( ) espírita
( ) evangélica
( ) tradicional
( ) pentecostal
( ) neo-pentecostal
( ) outra, qual:
( ) não tem religião

11. A religião do pai desta criança:
( ) católica
( ) budista
( ) espírita
( ) evangélica
( ) tradicional
( ) pentecostal
( ) neo-pentecostal
( ) outra, qual:
( ) não tem religião

12. Já tinha filhos antes deste parto?
( ) sim Quantos?
( ) não 

13. Tipo de partos tidos anteriormente:
( ) parto normal com episiotomia
( ) parto normal sem episiotomia
( ) parto cesáreo
( ) parto a fórcipe

14. Onde você mora existe banheiro de uso exclusivo dos moradores?
( ) $\operatorname{sim}$
( ) não

15. Onde você mora existe banheiro que só você e seu companheiro usam?
( ) não
( ) $\operatorname{sim}$

16. No banheiro que você usa no local onde você mora tem:
( ) chuveiro
( ) bidê ou duchinha
( ) pia com torneira
( ) banheira ou ofurô
( ) outro

17. No local onde você trabalha tem banheiro de uso exclusivo dos funcionários?
( ) não
( ) $\operatorname{sim}$

18. No banheiro que você usa no local de trabalho existe:
( ) chuveiro
( ) bidê ou duchinha
( ) pia com torneira
( ) banheira com ofurô ( ) outro

19. Para lavar suas roupas íntimas você usa:
( ) água e sabonete
( ) água e sabão em pó
( ) água e sabão em pedra
( ) outros produtos Qual:

20. Como você lava suas roupas íntimas:

( ) na mão ( ) na máquina de lavar roupa ( ) no tanquinho e torce na mão

( ) de outro jeito Como lava?

21. Como você seca suas roupas íntimas:
( ) no varal exposto ao sol
( ) dentro do Box do chuveiro
( ) de outro jeito? Como seca?
( ) em local onde não bate sol
( ) na secadora

22. Você usou absorventes higiênicos externos (tipo modess) durante a gravidez?
( ) não
( ) $\operatorname{sim}$
Caso sim com que freqüência você usou?
( ) sempre
( ) sempre que precisava
( ) às vezes

23. Você usou absorventes higiênicos internos (tipo OB) durante a gravidez?

( ) não ( ) sim

Caso sim com que freqüência você usou?
( ) sempre
( ) sempre que precisava
( ) às vezes

24. Qual é o seu hábito de higiene após fazer xixi:

( ) não realiza nenhum procedimento

( ) enxuga o local onde sai o xixi com papel higiênico

( ) enxuga o local onde sai o xixi com lenço umedecido

( ) enxuga com papel higiênico com movimento de frente para trás

( ) enxuga com papel higiênico com movimento de trás para a frente

( ) limpa com lenços umedecidos com movimento de frente para trás

( ) limpa com lenços umedecidos com movimento de trás para a frente

( ) lava a região genital apenas com água

( ) lava a região genital com água e sabonete

( ) outro, qual 


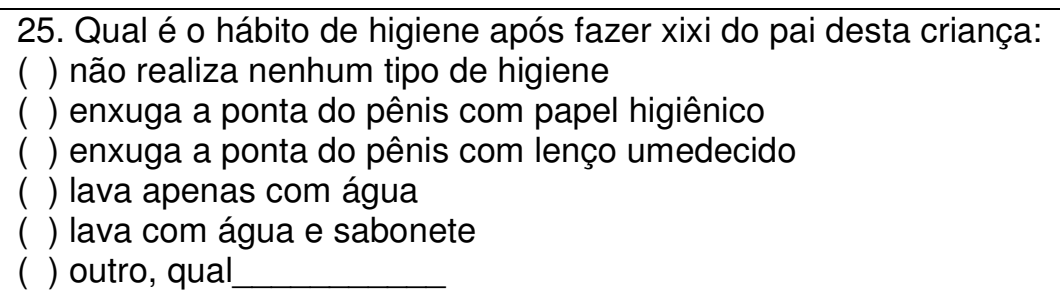

26. Qual é o seu hábito de higiene após fazer cocô:

( ) não realiza nenhum procedimento

( ) enxuga o local onde sai o cocô com papel higiênico

( ) enxuga o local onde sai o cocô com lenço umedecido

( ) enxuga com papel higiênico com movimento de frente para trás

( ) enxuga com papel higiênico com movimento de trás para a frente

( ) limpa com lenços umedecidos com movimento de frente para trás

( ) limpa com lenços umedecidos com movimento de trás para a frente

( ) lava apenas com água

( ) lava com água e sabonete

( ) outro, qual

27. Qual é o hábito de higiene após evacuar do pai desta criança:

( ) não realiza nenhuma higiene

( ) enxuga o local onde sai o cocô com papel higiênico

( ) enxuga o local onde sai o cocô com lenço umedecido

( ) enxuga com papel higiênico com movimento de frente para trás

( ) enxuga com papel higiênico com movimento de trás para a frente

( ) limpa com lenços umedecidos com movimento de frente para trás

( ) limpa com lenços umedecidos com movimento de trás para a frente

( ) lava apenas com água

( ) lava com água e sabonete

( ) outro, qual

28. Quantos parceiros sexuais você teve nesta gestação:
( ) um
( ) dois
( ) três
( ) quatro ou mais
( ) nenhum

29. Que tipo de relação sexual que você teve durante nesta gestação:
( ) somente vaginal
( ) somente oral
( ) somente anal
( ) oral e vaginal
( ) oral e anal
( ) oral, vaginal e anal
( ) nenhum

30. Com que freqüência você teve relação sexual nesta gestação:
( ) mais que uma vez por dia
( ) uma vez por dia
( ) uma vez por semana ( ) duas vezes por semana ( ) três vezes por semana
( ) a cada duas semanas ( ) uma vez por mês
( ) não tive relação depois que engravidei

31. Qual foi o seu hábito de higiene mais freqüente antes das relações sexuais nesta gravidez:

( ) não realizou nenhum procedimento de higiene

( ) Limpou por dentro da vagina com água

( ) Limpou por dentro da vagina com água e sabonete

( ) lavou a região genital apenas com água

( ) lavou a região genital com água e sabonete

( ) tomou banho de chuveiro

( ) tomou banho de banheira ou ofurô

( ) outro, qual 
32. Como foi hábito de higiene do seu parceiro antes das relações sexuais nesta gravidez:

( ) não realizou nenhum procedimento de higiene

( ) lavou o pênis apenas com água

( ) lavou o pênis com água e sabonete

( ) lavou toda a região genital apenas com água

( ) lavou toda a região genital com água e sabonete

( ) tomou banho de chuveiro

( ) tomou banho de banheira ou ofurô

( ) outro, qual

33. Como foi seu hábito de higiene mais freqüente depois das relações sexuais nesta gravidez:

( ) não realizou nenhum procedimento de higiene

( ) limpou a região genital com papel higiênico

( ) Limpou por dentro da vagina com água

( ) Limpou por dentro da vagina com água e sabonete

( ) lavou a região genital apenas com água

( ) lavou a região genital com água e sabonete

( ) tomou banho de chuveiro

( ) tomou banho de banheira ou ofurô

( ) outro, qual

34. Como foi o hábito de higiene mais freqüente do seu parceiro após as relações sexuais nesta gravidez:

( ) não realizou nenhum procedimento de higiene

( ) lavou o pênis apenas com água

( ) lavou o pênis com água e sabonete

( ) lavou toda a região genital apenas com água

( ) lavou toda a região genital com água e sabonete

( ) tomou banho de chuveiro

( ) tomou banho de banheira ou ofurô

( ) outro, qual

35. Você recebeu orientações sobre higiene genital no pré-natal desta gravidez?

( ) não ( ) sim

Qual profissional deu as orientações?

36. O seu parceiro recebeu orientações sobre higiene genital no pré-natal desta gravidez?

( ) Não

( ) Sim

Qual profissional deu as orientações?

37. Você teve algum destes sintomas durante esta gravidez?
( ) dor ao urinar
( ) urgência para urinar
( ) Dor nas costas
( ) Febre ( ) urina com presença de sangue
( ) dor no baixo ventre

38. Você teve infecção de trato urinário durante a gestação?

( ) não

( ) não sabe informar

( ) $\operatorname{sim}$

Só as mulheres que tiveram infecção urinária devem responder às questões seguintes:

39. Você tratou a infecção urinária tomando medicamento (antibiótico)?
( ) não
( ) $\operatorname{sim}$

40. Você recebeu orientações sobre como prevenir a infecção urinária na gravidez
( ) não
( ) $\operatorname{sim}$ 
